Jørgen Alnæs

Høgskolelektor

Institutt for journalistikk og mediefag

Høgskolen i Oslo og Akershus

Thore Roksvold

Professor

Institutt for journalistikk og mediefag

Høgskolen i Oslo og Akershus

\title{
Etosimplikaturer i lanseringsjournalistikk
}

\section{Sammendrag}

Avisjournalistikk er gjerne strategisk kommunikasjon. Journalisten har en intensjon om å fylle redaksjonelle rammer; kilden ønsker å framstå mest mulig positivt med sitt cerend. Derfor kan det ofte hende at avisteksters grunnleggende orend er et annet enn det tilsynelatende. Dette andre cerendet framstår $i$ stor grad implisitt $i$ teksten, men kan etter vårt syn identifiseres ved analyse av semantiske og pragmatiske implikaturer (Sigrell 2001). Gjennom analysen og begrepsbruken håper vi å konkretisere og vise hva tolkingsaktivitet kan vare, og hvordan etisk problematiske trekk er innbakt $i$ tekst og kontekst $i$ et oppslag som viser seg å vare en pseudonyhet. Som case velges et Dagbladet-intervju med kjendisartisten Bjørn Eidsvåg og en anmeldelse av en CD han samtidig ga ut. Analysen søker å få fram hvordan Eidsvåg og Dagbladet ønsker at Eidsvåg skal framstå, hvordan han framstår eksplisitt på oppslagets premisser og hvordan han framstår implisitt i teksten. Case-analysen får fram hvordan etosetablering ved henholdsvis semantiske og pragmatiske implikaturer er relatert til sjanger. $V i$ bruker segmenteringsanalyse av implikaturer $i$ både Eidsvåg-intervjuet og anmeldelsen. Den får fram sjangerforskjeller blant annet ved at bygging av skribentens etos er scerlig sentral $i$ anmeldelsen, først og fremst realisert ved pragmatiske implikaturer. Pragmatiske implikaturer realisert ved evaluative språkhandlinger karakteriserer anmeldelsen som sjanger. Segmenteringsanalysen får også fram at den skribentetos Dagbladet setter på spill $i$ intervjuet, delvis restaureres $i$ anmeldelsen. Analysen brukes som utgangspunkt for en diskusjon av problematiske sider ved lanseringsjournalistikk - med relevans for de presseetiske regler $i$ Var varsom-plakaten.

\section{Innledning}

Vi ønsker i denne artikkelen å vise hvordan en retorisk analyse av et avisoppslag kan gjennomføres for å etablere en forståelse av hvorfor og hvordan oppslaget er kommet i stand. 
Det er altså en analyse av samspillet mellom tekst og kontekst der vi prøver ut en metode for å analysere implisitte budskap - med særlig henblikk på etosetablering.

Caset vi analyserer, er et nyhetsoppslag med intervju og bilde av Bjørn Eidsvåg der han hevder han er blitt presset til å gi ut en biografi om seg selv, og at han angrer i ettertid. I artikkelen kommer det også fram at han er aktuell med en ny CD. Denne CD-en blir vurdert i en anmeldelse som står sammen med intervjuet. Vi vil analysere samspillet mellom nyhetsoppslaget og anmeldelsen i retorisk og presseetisk perspektiv.

Et samarbeid mellom en kilde og et medieorgan kan ofte være fruktbart for begge parter. Avisa, TV- eller radiokanalen kan få et godt oppslag, og kilden kan få oppmerksomhet. Ofte er begge tjent med at samspillet dem imellom ikke framstår som et planlagt samarbeid. Dette gjelder ikke minst i saker hvor kilden kan få økonomisk avkastning av oppmerksomheten. Da er det viktig for kilden å framstå som autentisk og ektefølt, ikke som en som er ute etter publisitet og penger. Samtidig er det viktig for medieorganet å vise sin uavhengighet og integritet; det må ikke se ut som om de der lar seg lure eller spiller med for å gi en oppmerksomhetssøkende kilde det han ber om. Pressens egne retningslinjer slår fast at «produktomtaler og produktplassering skal vore journalistisk motivert» (Tekstreklameplakaten punkt 1) og advarer mot ukritisk bruk av kilder, spesielt kilder som tilbyr eksklusivitet (Vær varsom-plakaten punkt 3.2).

Samspillet mellom kilde og medieorgan er gjerne tonet ned og tilslørt i teksten, men avdekkes ved kritisk analyse og tolking av implisitt informasjon. Slik tilsløring kan være problematisk av to årsaker: 1) Er det et tett forhold mellom kilden og journalisten, vil det være etisk problematisk å tildekke dette forholdet. Det vil grense til manipulasjon. 2) Ei slik tildekking vil dernest være retorisk problematisk fordi den vil stå i fare for å bli avdekket - og det vil slå tilbake på medieorganets troverdighet.

Det er altså interessant å undersøke hvordan samarbeidet mellom en kilde og et medieorgan framstilles som mest mulig tilforlatelig. En måte å undersøke dette på, er å gå nært på teksten og beskrive hvordan det implisitte budskapet formidles. Da blir det synlig i hvilken grad medieorganet legger til rette for fortolkningen, og hvilke grep som er tatt for å tildekke samarbeidet. Dette lar seg vanskelig avdekke i en kvantitativ innholdsanalyse, en diskursanalyse som ikke går tett inn på teksten, eller i en rammeanalyse som overser eventuelle implisitte budskap.

I kjendisjournalistikken er samarbeidet mellom kilde og medieorgan spesielt interessant. Kjendiser fanger oppmerksomheten fordi de er kjendiser, og publikum leser nysgjerrig kjendisoppslag for å få vite hvordan kjendisene "har det”. Følgelig slår mediene opp kjendisstoff for å få større publikum - flere lesere, lyttere og seere. Kjendisene på sin side lever ofte av nettopp å være kjendiser. Deres yrkesutøvelse er gjerne knyttet til det å være kjent. Det gjelder kongelige, politikere, kunstnere, kulturpersonligheter, sportsprofiler, journalistprofiler og artister. De er avhengige av offentligheten for å holde seg $\mathrm{i}$ folks bevissthet. Publisitet stimulerer deres salg av seg selv og sine produkter, og publisitet forutsetter medieeksponering. På samme måte som det foreligger en symbiose mellom sport og medier, foreligger det en symbiose mellom kjendiser og medier (Helland 2003; Dahlén 2008). Mediene bruker kjendisene for å øke salget av egne produkter og reklameplass, og 
kjendisene bruker mediene til å promotere seg selv og sine produkter. De har gjensidig fordel av å bruke hverandre. Symbioseforholdet mellom journalist og kilde kan beskrives i et bytteteoretisk perspektiv, som er basert på handelsprinsippet om tilbud og etterspørsel av en vare; journalister og kilder bytter informasjon mot oppmerksomhet (Kristensen 2004, s. 71; Sogn 2012; Allern 1997, s. 48).

Hvis kjendisen er en politiker, fester vi lit til politikerens budskap hvis politikeren framstår med en sterk etos for oss. Tilsvarende gjelder for de andre kjendistypene. En artist er avhengig av medieeksponering for å gi utgivelsen størst mulig oppmerksomhet. Hvordan kan artisten da bruke sitt image for å få medieeksponering? Og hvordan virker symbiosen mellom kjendiser og medier når kjendiser får medieoppmerksomhet?

I denne artikkelen vil vi belyse følgende spørsmål: 1) Hvordan etableres etos implisitt i teksten som blir analysert? 2) Hva slags typer implikatur er det særlig som etablerer etos i de foreliggende tekstene, og hvordan kan dette knyttes til sjanger? 3) Hvordan kan en detaljert analyse på tekstnivå belyse relasjonen mellom kjendis og medium?

\section{Viktige begreper}

\section{Etos}

Det eksplisitte og det implisitte i en tekst samvirker i etablering av etos, som vi kan oversette med "troverdighet", som igjen betyr "verdig til å bli trodd på". En som er verdig til å bli trodd på, får vår tillit og sympati. Både kjendisene og medieorganet søker kontinuerlig å bekrefte sin etos. Det henger nødvendigvis sammen med symbiosen mellom kjendiser og medier. Intervjuobjekter konstruerer sin etos, og journalistene konstruerer både sin, intervjuobjektenes og mediets. Dette er den etos som utformes i teksten - avledet etos (Kjeldsen 2004, s. 126; McCroskey 2006, s. 90ff).

Det er tre ting som gjør en taler overbevisende, skriver Aristoteles. Det er hans forstand, hans personlige karakter og hans velvillige innstilling (Aristoteles 2006, s. 104). Bare hvis taleren har en god karakter og god vilje, kan vi være sikre på at han sier hva han mener. Men hva kjennetegner en god karakter? Aristoteles henviser til sin diskusjon av «Hva som fortjener ros», der han blant annet trekker fram dydene rettskaffenhet, mot, selvbeherskelse, storslåtthet, generøsitet, gavmildhet, mildhet, fornuft og visdom (2006, s. 63). Velvilje omtaler Aristoteles som å ønske noen et gode eller gjøre en god gjerning for den andres skyld, ikke for at man selv skal oppnå noe (2006 s. 117, s. 131).

Aristoteles' tre etosdimensjoner har vært utgangspunktet for McCroskeys tre dimensjoner: kompetanse, karakter og goodwill eller «perceived caring», men er ikke helt de samme (McCroskey, 2006, s. 86). Kompetanse er noe snevrere enn Aristoteles' forstandighet/klokskap. Å ha "perceived caring" eller goodwill hevder McCroskey er å være empatisk, forståelsesfull og lydhør.

Anders Johansen har trukket fram et aspekt som vil styrke en persons troverdighet, og det er autentisiteten (2002, s. 71-73). Han hevder at blant annet på grunn av moderne mediers mulighet til å skape nærhet til politikere har mennesket kommet i sentrum, framfor saka. Folk vet at politisk kommunikasjon er strategisk; derfor er det viktig for en politiker å framstå som 
menneskelig og naturlig og vise at man mener det man sier, og at man "er seg selv". Autentisitet knytter seg nærmest opp mot karakter. Johansen hevder at autentisitet kan overskygge spørsmålet om kompetanse og spørsmålet om sannhet og løgn: «Å snakke sant er ingenting mot å vaere sann» (2002, s. 80). Jens Elmelund Kjeldsen har oppsummert tre sider ved en autentisk væremåte: 1) å ikke framstå som iscenesatt, 2) å framstå som intim, personlig og ekte engasjert, 3) å være konsekvent i situasjonen og over tid (Kjeldsen 2004, s. 121).

I forsøket på å finne generelle aspekter ved etos er man nødt til å overse det situasjonelle. Dette er problematisk, fordi enhver retorisk situasjon er unik, og enhver mottaker er unik (Kjeldsen 2004, s. 143f). Slik har både Aristoteles', McCroskeys og Johansens teorier begrensinger og kan ikke gi oss endelige svar på hva publikum vil oppfatte som troverdig. Vi kan altså ikke operere med et fullstendig system, men det er heller ikke ønskelig. Disse ulike teoriene kan hjelpe oss med å diskutere hvordan Eidsvågs etos virker, og hvordan det eventuelt kan virke på ulike måter i ulike sjangrer.

En kommentarartikkel er en mer åpent logisk argumenterende tekst enn et intervju, der etos i større grad utvikles også gjennom narrasjon. Det implisitte behøver ikke være logiske argumenter. Det kan være kunnskap, holdninger, normer, myter og fortolkningsrammer (Tuchman 1978). Hellspong (2000) trekker også inn «berättelser». Nyhetsartikkelen vi har valgt å analysere, er mer fortellende enn argumenterende. Dermed blir det mulig å trekke inn også andre overbevisningsgrunner enn de logiske.

Inntrykket vi får av en person, skapes av eksplisitte beskrivelser eller betegnelser, for eksempel «Den populære artisten», men også av hva vedkommende sier og gjør, og måten dette framstilles på. Slik etableres etos ofte implisitt. Derfor mener vi at en analyse av hvordan etos etableres, innebærer en analyse av implikaturer.

\section{Implikatur}

Implikaturer er implisitte sammenhenger. De formidler hva noe innebærer. En norsk oversettelse av implikatur kunne være "innebæring". Vi vil i vår analyse skille mellom semantisk og pragmatisk implikatur (Levinson 2000, s. 168, s. 243).

Mellomtittelen «Følte seg presset» i artikkelen «Presset til å gi ut boka om seg selv» innebærer at Eidsvåg var i en tvangssituasjon. Han måtte gjøre som han gjorde. Dette er hva vi vil kalle semantisk implikatur. Hva vi skal utlede i implikaturen, er språklig innbakt i utgangssetningen, i ordet «presset». Er vi i tvil om vi har å gjøre med semantisk implikatur, kan vi bruke en substitusjonstest: Hvis vi, ved å bytte ut et ord med et annet, kan endre implikaturen, men i grove trekk beholde betydningen i ytringen, har vi å gjøre med semantisk implikatur. Bytter vi ut «presset» med «lokket» eller «oppfordret», vil innholdet være noenlunde det samme, men implikaturen er endret. Et annet eksempel er overskriften «CV». Implikaturen her er at Eidsvåg og Dagbladet er seriøse. Innholdet i overskriften endres ikke mye om vi isteden skriver «Livsløp», «Eidsvågs liv og virke» eller «Dette er hva Eidsvåg har fått ut av livet», men implikaturen blir en annen.

Pragmatiske implikaturer er ikke språklig innbakt i den realiserte utgangsytringa, men kan utledes av konteksten. «Følte seg presset» innebærer også at siden Eidsvåg var i en tvangssituasjon og måtte gjøre som han gjorde, kan han ut fra våre sosiale og kulturelle 
normer ikke lastes for at biografien ble gitt ut. Han er altså ikke skurk, men offer. Han fortjener medynk mer enn forakt, og det styrker hans etos. Det vil vi si er en pragmatisk implikatur.

Skillet mellom semantisk og pragmatisk implikatur er nødvendig for å presisere hvordan det implisitte budskapet kan utledes. Det vil også gjøre det lettere å peke på hvordan dette er kommunisert. En kilde som uttaler seg til en avis, vil til en viss grad ha kontroll på det underforståtte budskapet i sine ytringer. De semantiske implikaturene vil være de samme, så lenge setningen ikke skrives om. Noe av det implisitte innholdet i ei ytring vil imidlertid være påvirket av konteksten. Får setningen en ny kontekst, kan den oppfattes på en annen måte, og vi kan utlede et nytt implisitt budskap av den. Da er det de pragmatiske implikaturene som har forandret seg. De pragmatiske implikaturene er det altså, i dette tilfellet, journalisten eller medieorganet som kontrollerer. Ved å skille mellom semantisk og pragmatisk implikatur kan vi lettere se hvordan kilde og journalist/medieorgan samvirker når et implisitt budskap etableres. Og vi ser lettere hvordan etos etableres i samspill mellom ordvalget i teksten og de kulturelle normene i konteksten.

Semantiske implikaturer velger vi å tolke ut fra innholdsorda i teksten - vesentlig på bakgrunn av denotasjon og konnotasjon. Pragmatiske implikaturer velger vi å tolke ut fra kulturell og sosial kontekst med sine normer og myter, den retoriske kommunikasjonssituasjonen og funksjonsord og språkhandlinger som er relatert til den verbale konteksten.

Språkhandlinger inngår i analysen av pragmatisk etos-implikatur, siden det er konteksten som avgjør hva slags språkhandling ei ytring utgjør. Konteksten avgjør om f.eks. påstanden «Du er trøtt» er fastslående eller vurderende. Hvis påstanden oppfattes som fastslående eller "konstativ", kan «trøtt» kan erstattes med det beskrivende adjektivet «søvnig» (Eriksson 1999, s. 4-5, s. 8). Hvis påstanden oppfattes som vurderende, kan «trøtt» erstattes med det karakteriserende adjektivet «kjedelig» (Togeby 1977). Vi velger å bruke termen "evaluativ" om vurderende språkhandlinger (Roksvold 2005, s. 25f). Språkhandlinger fortolkes ut fra kommunikasjonsnormer.

For å utlede pragmatisk implikatur bruker vi vår kunnskap om både situasjonskonteksten, den tekstuelle konteksten og kulturkonteksten (Hågvar 2007, s. 30-31). Den tekstuelle konteksten til ei ytring vil i vår sammenheng både være den konkrete teksten som ytringa er en del av, men også andre faktiske tekster, eller spor av andre tekster. På denne måten dreier analysen av pragmatisk implikatur seg i noen grad om å avdekke tekstens intertekstualitet. Fairclough skiller mellom to typer intertekstualitet, nemlig «manifest intertextuality» og «interdiscursivity» (Fairclough 1993, s. 85). Per Ledin bygger på disse to begrepene når han skiller mellom «tekstsamspill» og «normsamspill». Tekstsamspill dreier seg om at hele eller deler av andre tekster er eksplisitt til stede i en annen tekst (Ledin 1997, s. 37). I en analyse av tekstsamspill vil hovedspørsmålet være «Vem har ordet?» (Ledin 1997, s. 45). Normsamspill dreier seg om et samspill mellom «olika slags discourse types eller textnormer» (Ledin 1997, s. 37). Discourse types består av «en uppsätting genrer, diskurser, stilar etc.». Hovedspørsmålet i en analyse av normsamspill vil være «Hur talar den som har ordet?»(Ledin 1997, s. 44). En analyse av pragmatisk implikatur vil kunne avdekke både 
tekstsamspill og normsamspill. For å utlede pragmatisk implikatur trekker vi blant annet på sjanger, diskurs, stil og andre konkrete tekster. Når vi utleder semantisk implikatur, trekker vi bare på vår semantiske kompetanse.

Tolking av semantiske og pragmatiske implikaturer kan ses som ulike omdreininger i den hermeneutiske sirkel, som Paul Ricoeur heller ser for seg som en spiral, når han skriver at forklaring «stems from the very sphere of language, by analogical transference from the small units of language (phonemes and lexemes) to the units larger than the sentence, such as narratives, folklore and myth» (Ricoeur 1981, s. 157). Hvert omdreiningspunkt også i vår analyse av Eidsvåg-oppslaget impliserer en bestemt lese- og fortolkingsstrategi - slik at å fortolke semantiske implikaturer foregår på et mer grunnleggende strukturelt nivå, mens pragmatiske implikaturer fortolkes på et overordna nivå i en semiologisk dimensjon som også impliserer myter og normer.

\section{Sjanger}

Per Ledin har en kort og presis sjangerdefinisjon: «En genre ser jag som en fast och återkommande uppsätting textnormer, som är bunden till en viss social aktivitet och som är namngiven» (Ledin 1997, s. 42). Carolyn Miller knytter sjanger til retoriske handlinger og argumenterer for at en sjangerdefinisjon «ikke må konsentrere seg om diskursens substans (innhold) eller form, men om den handlingen den blir brukt til å utføre» (Miller 2001, s. 20). De to journalistiske sjangrene vi har undersøkt, anmeldelsen og nyhetsartikkelen, er begge en del av en informasjons- og meningsformidling som foregår i avisa, men de brukes ulikt og kan knyttes til ulike språkhandlinger. Nyhetsartikkelen formidler hvordan noe er (konstativ), mens anmelderen formidler sine opplevelser (ekspressiver) av noe og sine vurderinger, som vi kaller evaluativer. Også nyhetsartikkelen formidler meninger og vurderinger, men da er det som regel intervjuobjektet som står for disse. Journalisten, forventer vi, er nøytral. Det er grunn til å tro at denne forskjellen vil resultere i ulike måter å bygge etos på. Dette vil vi undersøke når tekstene segmenteres.

Også Norman Fairclough knytter sjanger til en handling eller en sosial aktivitet:

I shall use the term 'genre' for a relatively stable set of conventions that is associated with, and partly enacts, a socially ratified type of activity, such as informal chat, buying goods in at shop, a job interview, a television documentary, a poem, or a scientific article. A genre implies not only a particular text type, but also a particular process of producing, distributing and consuming texts (Fairclough 1992, s. 126).

En sjanger kjennetegnes altså ikke bare ved innholdsmessige og formelle trekk, men også gjennom måten den er produsert på, og måten den leses på. I vårt tilfelle sammenlikner vi to tekster i samme avis og samme oppslag. De tilhører to ulike sjangrer, og dette innebærer blant annet at de er produsert på ulike måter. En del av produksjonen av intervjuet har vært en samtale med intervjuobjektet, en del av produksjonen av anmeldelsen har vært å fordype seg $\mathrm{i}$ et produkt, i dette tilfelle en CD.

Som Fairclough peker på, innebærer en sjanger også at teksten oppfattes og brukes på en bestemt måte. Den mest innlysende forskjellen på en anmeldelse og en nyhetsartikkel i 
dette henseende er nok at avislesere flest vet at de finner hovedpoengene tidlig i nyhetssaken, mens de finner konklusjonen mot slutten av en anmeldelse. Derfor vil en leser skumlese de to tekstene på helt ulike måter. Men det finnes også andre forskjeller knyttet til leserens forventinger. Siden anmelderens vurdering står sentralt i anmeldelsen, mens journalistens formidling av fakta og synspunkter er det sentrale i nyhetsartikkelen, vil leseren være opptatt av begge skribentenes etos, men muligens i ulik grad og på ulik måte. Nyhetsartikkelen er imidlertid ingen heterogen sjanger, og det er grunn til å tro at leserne har ulike forventninger til journalistens integritet også i ulike nyhetsartikler.

\section{Eidsvåg-intervjuet med bilde}

Et poeng med vår analyse er å vise hvordan sjangerforskjeller fordrer ulik retorisk strategi i etablering av etos som implisitt budskap i teksten, og hvordan strategien for å analysere implisitt etablering av etos også blir ulik for tekster i ulike sjangrer. Tekstene som analyseres, vil, som nevnt, bli segmentert (Hågvar 2007, s. 56ff). Vi lar utsagn i tittel, eller utsagn som avsluttes av stort skilletegn (periode), utgjøre et segment. Hvis flere perioder etter hverandre har samme etos-implikatur(er), slår vi dem imidlertid sammen.

De foreliggende segmenteringsanalysene er tenkt som praktiske eksempler på diskursanalyse der teksten er i sentrum. Samfunnsvitenskapelige diskursanalyser beskriver sosial praksis og diskursiv praksis, men mangler ofte metode for å beskrive teksten inngående (Fairclough 2008, s. 29). Det er derfor også et poeng med denne analysen å eksemplifisere ei retorisk metodisk tilnærming til diskursanalyse av tekst. Analysen er ment å være kritisk ved at vi i siste kolonne i segmenteringsskjemaet problematiserer etos-implikaturene vi analyserer fram. Til slutt følger - på bakgrunn av tekstanalysen - noen betraktninger knyttet til spørsmåla nevnt innledningsvis om symbiosen mellom kjendiser og medier.

I oppslaget er bildet det første tekstelementet som etablerer etos. Det er slått stort opp både på førstesida og inne i avisa. Ved analyse av bildet er det særlig fruktbart å beskrive konnotasjonene. På denotasjonsnivået ser vi et mannsansikt. Personen på bildet identifiseres som Eidsvåg. Han har skjegg og langt hår, som godt kan konnotere artist. Han holder venstre håndflate foran det ene øyet, som er skjult. Det andre ser skrått ned, litt til venstre for betrakteren. At Eidsvåg ikke har øyekontakt med betrakteren, kan tyde på unnvikenhet, men øyet ser verken skamfullt eller trist ut (Øyslebø 1988, s. 132f). En halvåpen munn med munnvikene trukket litt opp kan være tegn på at han snakker, eller at han har smilt eller ledd. Hånda kan indikere at han verger seg, fordi han føler frykt eller engstelse. Det kan også skyldes at han skjuler seg, fordi han skammer seg eller er uærlig. Det kan da også hende at Eidsvåg tørker ei tåre, fordi han er trist, eller fordi han nettopp har ledd. Spor av smil i munnvikene kan tyde på det siste. I så fall står bildet dårlig til teksten som er lagt oppå bildet.

På førstesida får vi vite at «Bjørn Eidsvåg angrer på biografien» (sgm 1), at han er «presset til INTIME betroelser» (sgm 2), og at han har det «TUNGT: Bjørn Eidsvåg bidro til sin egen biografi for å ødelegge for en konkurrent. Nå angrer han» (sgm 3). Inne i avisa ligger verbalteksten «Bjørn Eidsvåg angrer på biografien» (sgm 4) og «PRESSET til å gi ut boka om seg selv» (sgm 5) oppå bildet. Tekstforankringa både på førstesida og inne i avisa 
styrer lesemåten i retning av at Eidsvåg verger seg eller skjuler seg med hånda. Men restene av smil rundt munnen og i øyekroken passer ikke med teksten. Når Dagbladet setter sammen tekst og bilde på denne måten, blir oppslaget tvetydig, og Eidsvåg framstår som uærlig. Det kan se ut som om han bare later som om han verger eller skjuler seg. Det kan også hende at han poserer etter anvisning fra fotografen. Eller det kan hende han bare klør seg i øyet. Men «generelt gjelder at alle former for å klø, gni eller på annen måte fikle ved egen kropp uttrykker en sinnsstemning. Bl.a. ved løgn og andre forsøk på å lure mottaker øker selvberøringen» (Øyslebø 1988, s. 193). Det er Dagbladet som med sin tekst prøver å styre måten vi skal oppfatte kroppsspråket i bildet på, og det er selvfølgelig Dagbladet som har valgt ut akkurat dette bildet. Når kroppsspråket så ikke harmonerer med fortolkningsramma som Dagbladet legger på bildet, er det kanskje Dagbladet som er uærlig (Tuchman 1978; Entman 1993; Allern 2001, s. 68f). Men leseren vil kunne oppfatte både Eidsvåg og Dagbladet som tvetydige, og denne tvetydigheten preger hele oppslaget.

Eksplisitt forteller teksten om hvorfor Eidsvåg tok kontakt med en biograf, og hvorfor han i ettertid har angret på dette. Teksten forteller også om Eidsvågs private økonomi og at Eidsvåg er glad han har god råd. Siste del av teksten handler om Eidsvågs nye album og innspillinga av det. Flere steder i teksten omtales personlige egenskaper ved Eidsvåg i klartekst. Dagbladet forteller om Eidsvåg at han «[l]ar seg ikke mobbe» og at han er en mann «som nyter opplevelsene fjellvandring og naturen gir ham». Dagbladet lar også Eidsvåg si at han «alltid har skjermet og vernet familien», at han har blitt «klokere, mindre høy på pcera» og har fått «større selvinnsikt». Sju ganger omtaler Dagbladet eller Eidsvåg eksplisitt egenskaper ved Eidsvåg. Hvis Eidsvåg har disse egenskapene, har han rimelig god etos, om vi ser etter en mann å kjøpe musikk av: Han har kompetanse til å lage musikk som selger, han er klok og fornuftig og har god karakter (han lar seg ikke mobbe eller skremme). Etosdimensjonen goodwill/velvilje omtales derimot ikke eksplisitt. Det står heller ikke noe eksplisitt om Eidsvågs autentisitet. Men som lesere forholder vi oss selvfølgelig også til det implisitte, og der nyanseres bildet av Eidsvåg.

Ved analyse av verbalteksten er det særlig nyttig å identifisere implikaturer, og undersøke hvordan de etablerer etos. For enkelhets skyld fører vi Eidsvågs og Dagbladets etos inn i ett og samme skjema. Semantisk implikatur forkorter vi til «sim» og pragmatisk implikatur til «pim».

I skjemaet som følger, er intervjuet fra oppslaget segmentert i venstre kolonne. I midtkolonnen beskrives hva slags etos som etableres gjennom semantisk og pragmatisk implikatur i segmentene. I høyre kolonne problematiserer vi segmentenes etos-implikatur.

Vi har to konkurrerende innholdssekvenser i teksten: biografisekvensen (sgm 1-6, 17 , 19-36 og 51-55) og promoteringssekvensen (sgm 7-16, 18 og 37-50) (Hågvar 2007, s. 80). Spillet mellom disse sekvensene skaper den tvetydigheten i oppslaget som vi allerede har påpekt $\mathrm{i}$ analysen av oppslagsbildet.

Spalten lengst til venstre $\mathrm{i}$ oppslaget inne i avisa er viet Eidsvågs CV. Overskriften «CV» konnoterer seriøsitet og faglig tyngde. Dette er, som vi har nevnt tidligere, semantiske implikaturer. Sannsynligvis leser de færreste hele CV-en før de begynner på teksten som er hovedoppslaget, men om leseren bare ofrer CV-en et kort blikk, vil den likevel, gjennom 
semantiske, men framfor alt pragmatiske implikaturer, gi både Dagbladet og Eidsvåg et solid utgangsetos - innledende etos (Kjeldsen 2004, s. 123; McCroskey 2006, s. 87ff).

CD-anmeldelsen er plassert lengst til høyre. Tittelen «Noen friske pust», undertittelen «Nesten irriterende på det jevne» og terningkastet (en firer) forteller at Dagbladet ikke utelukkende stryker Eidsvåg med hårene, og at avisa er selvstendig og profesjonell overfor kildene sine. Pragmatiske implikaturer i anmeldelsens tittel og undertittel vil være at «Dagbladet har integritet».

Bjørn Eidsvågs etos bygges særlig i den første delen av teksten (sekvensene 1-27). Problematiseringene i høyre kolonne av segmenteringsskjemaet påpeker forholdet eller misforholdet mellom det som kommuniseres eksplisitt, og det som er implisitt. Det som kommuniseres eksplisitt, er tilforlatelig etosbygging. Det som kommuniseres gjennom semantiske og pragmatiske implikaturer er mer problematisk, og kan i større grad diskuteres:

\begin{tabular}{|c|c|c|c|}
\hline Segmentert tekst & $\begin{array}{l}\text { Semantisk etos- } \\
\text { implikatur } \\
\text { (sim) }\end{array}$ & $\begin{array}{l}\text { Pragmatisk } \\
\text { etos- } \\
\text { implikatur } \\
\text { (pim) }\end{array}$ & Problematisering \\
\hline $\begin{array}{l}\text { 1) Bjørn Eidsvåg } \\
\text { angrer på biografien } \\
\text { (Overtittel s. 1) }\end{array}$ & & $\begin{array}{l}\text { Bjørn } \\
\text { Eidsvåg (BE) } \\
\text { er } \\
\text { åpenhjertig. }\end{array}$ & \\
\hline $\begin{array}{l}\text { 2) - presset til } \\
\text { INTIME betroelser } \\
\text { (Hovedtittel s. 1) }\end{array}$ & $\begin{array}{l}\text { BE er et offer } \\
\text { (sim pga. } \\
\text { «presset»). }\end{array}$ & & $\begin{array}{l}\text { Dagbladet uthever ordet } \\
\text { «intime». I artikkelen bruker } \\
\text { ikke BE selv det ordet. } \\
\text { Likevel utlegger Dagbladet } \\
\text { ved hjelp av replikkstrek både } \\
\text { «presset» (som BE heller ikke } \\
\text { bruker i noen replikk i } \\
\text { artikkelen) og «intime» som } \\
\text { BE-sitater. Det er tydelig at } \\
\text { Dagbladet ønsker å framstille } \\
\text { BEs situasjon som mer } \\
\text { vanskelig enn det han selv har } \\
\text { gjort. Slik styrker Dagbladet } \\
\text { BEs etos. Samtidig spiller de } \\
\text { høyt med sin egen etos, og } \\
\text { stoler på at leseren ikke } \\
\text { legger merke til } \\
\text { uoverensstemmelsen mellom } \\
\text { tittel og ingress. }\end{array}$ \\
\hline $\begin{array}{l}\text { 3) TUNGT: Bjørn } \\
\text { Eidsvåg bidro til sin } \\
\text { egen biografi for å } \\
\text { ødelegge for en } \\
\text { konkurrent. Nå angrer } \\
\text { han. (Bildetekst s. 1) }\end{array}$ & & $\begin{array}{l}\text { BE er en } \\
\text { antihelt. }\end{array}$ & $\begin{array}{l}\text { Hvor edelt er det å ødelegge } \\
\text { for en konkurrent? At BEs } \\
\text { motiv for å gi ut sin egen } \\
\text { biografi var å ødelegge for en } \\
\text { konkurrent, undergraver } \\
\text { framstillinga av BE som et }\end{array}$ \\
\hline
\end{tabular}




\begin{tabular}{|c|c|c|c|}
\hline & & & $\begin{array}{l}\text { offer under press. Dermed } \\
\text { kan BE oppfattes som mindre } \\
\text { edel, og Dagbladets etos } \\
\text { svekkes ved at grunnlaget for } \\
\text { å framstille BEs situasjon } \\
\text { som press er mindre entydig. }\end{array}$ \\
\hline $\begin{array}{l}\text { 4) Bjørn Eidsvåg } \\
\text { angrer på biografien } \\
\text { (Overtittel s. 50) }\end{array}$ & & Som sgm 1. & \\
\hline $\begin{array}{l}\text { 5) PRESSET til å gi } \\
\text { ut boka om seg selv } \\
\text { (Hovedtittel s. 50-51) }\end{array}$ & $\begin{array}{l}\text { BE er et offer } \\
\text { (sim pga. } \\
\text { «presset»). }\end{array}$ & & $\begin{array}{l}\text { «Presset» angis som et } \\
\text { faktum. Er det dekning for } \\
\text { det? Personen som skulle ha } \\
\text { utøvd presset, hevder det } \\
\text { motsatte. Igjen spiller } \\
\text { Dagbladet høyt med sin egen } \\
\text { etos for å framstille } \\
\text { omstendighetene rundt BEs } \\
\text { handlinger som formildende. } \\
\text { Dagbladet styrker sin etos } \\
\text { ved å bringe konkurrentens } \\
\text { motsvar ukommentert, men } \\
\text { etos framstår som svekket når } \\
\text { dette kontrasteres med } \\
\text { vinklinga av saka (BE som et } \\
\text { presset offer). }\end{array}$ \\
\hline $\begin{array}{l}\text { 6) Ble plaget: Bjørn } \\
\text { Eidsvåg skulle gjerne } \\
\text { sett at boka om ham } \\
\text { aldri ble utgitt. Han } \\
\text { følte seg presset til å } \\
\text { gi ut biografien, som } \\
\text { kom i fjor - En } \\
\text { tvilsom fyr plaget og } \\
\text { presset meg om (sic! } \\
\text { Vår komm.) mine } \\
\text { nærmeste for } \\
\text { opplysninger. For å } \\
\text { komme ham i } \\
\text { forkjøpet, tok jeg selv } \\
\text { kontakt med en annen } \\
\text { biograf, sier Eidsvåg. } \\
\text { (Bildetekst s. 50-51 ) }\end{array}$ & $\begin{array}{l}\text { BE er et offer } \\
\text { (sim pga. } \\
\text { «presset»). }\end{array}$ & $\begin{array}{l}\text { BE er et godt } \\
\text { menneske. } \\
\text { BE er } \\
\text { anstendig, } \\
\text { siden han } \\
\text { ikke navngir } \\
\text { den } \\
\text { tvilsomme } \\
\text { fyren. }\end{array}$ & $\begin{array}{l}\text { Den tvilsomme fyren er ikke } \\
\text { navngitt, verken av BE eller } \\
\text { av Dagbladet. Holder BE } \\
\text { navnet hans hemmelig for å } \\
\text { være diskret eller for desto } \\
\text { friere å kunne omtale } \\
\text { vedkommende negativt? Hvis } \\
\text { det siste er tilfelle, framstår } \\
\text { BE som uhederlig. «Følte seg } \\
\text { presset» er mer forbeholdent } \\
\text { enn «[var/ble] presset» i sgm } \\
2 \text { og } 5 .\end{array}$ \\
\hline $\begin{array}{l}\text { 7) «Det var } \\
\text { utleverende og ble en } \\
\text { belastning, ikke bare } \\
\text { for meg, men for } \\
\text { familien, venner og } \\
\text { kolleger.» Bjørn }\end{array}$ & $\begin{array}{l}\text { BE er } \\
\text { familiekjær. }\end{array}$ & $\begin{array}{l}\text { BE er et } \\
\text { offer. Han } \\
\text { har vært naiv, } \\
\text { men er ærlig. } \\
\text { Det er synd } \\
\text { på BE, som }\end{array}$ & $\begin{array}{l}\text { BE appellerer til patos når } \\
\text { han trekker inn familie, } \\
\text { venner og kolleger. Vi får } \\
\text { ikke vite hvordan disse er } \\
\text { blitt belastet. }\end{array}$ \\
\hline
\end{tabular}




\begin{tabular}{|c|c|c|c|}
\hline $\begin{array}{l}\text { Eidsvåg (Sitat s. 50, } \\
\text { trukket ut fra teksten) }\end{array}$ & & $\begin{array}{l}\text { dog makter å } \\
\text { vise omtanke } \\
\text { for andre. }\end{array}$ & \\
\hline $\begin{array}{l}\text { 8) Biografien om } \\
\text { Bjørn Eidsvåg har } \\
\text { vært en stor } \\
\text { belastning for ham og } \\
\text { familien. Den } \\
\text { populære artisten } \\
\text { angrer på at han } \\
\text { fortalte om sitt liv. }\end{array}$ & & $\begin{array}{l}\text { Som sgm } 7 . \\
\text { (At BE er } \\
\text { populær, er } \\
\text { her semantisk } \\
\text { presupponert, } \\
\text { ved at } \\
\text { nominal- } \\
\text { hypotagmet } \\
\text { står i bestemt } \\
\text { form.) }\end{array}$ & $\begin{array}{l}\text { Se sgm 7. Adjektivet «stor» } \\
\text { kan forsterke } \\
\text { medynksfølelsen. Adjektivet } \\
\text { «populære» forstørrer } \\
\text { kontrasten mellom suksess og } \\
\text { feilgrep. Adjektiva er } \\
\text { virkemidler i Dagbladets } \\
\text { patos-retorikk. Gjennom } \\
\text { bruken av «populære» } \\
\text { etablerer Dagbladet en egen } \\
\text { kontekst som styrer lesinga } \\
\text { av segment 9. } \\
\text { Kontekstvirkningen hadde } \\
\text { blitt en annen om de } \\
\text { istedenfor «populære» hadde } \\
\text { skrevet for eksempel } \\
\text { «styrtrike». }\end{array}$ \\
\hline $\begin{array}{l}\text { 9) - Angrer, ja. Jeg } \\
\text { bebreider ikke biograf } \\
\text { Randi Berge } \\
\text { Svendsen, hun gjorde } \\
\text { en god jobb. Men jeg } \\
\text { ville ikke tatt initiativ } \\
\text { til boka i dag, sier } \\
\text { Bjørn Eidsvåg. }\end{array}$ & $\begin{array}{l}\text { BE er storsinnet } \\
\text { (sim pga. } \\
\text { «bebreider } \\
\text { ikke»). }\end{array}$ & $\begin{array}{l}\text { Teologen BE } \\
\text { er en } \\
\text { angrende } \\
\text { synder. Han } \\
\text { lærer av sine } \\
\text { feil. }\end{array}$ & $\begin{array}{l}\text { Siden biografen «gjorde en } \\
\text { god jobb», bør kanskje } \\
\text { leseren kjøpe boka. Nevnes } \\
\text { boka for å promoteres igjen? I } \\
\text { så fall er BE kynisk. }\end{array}$ \\
\hline $\begin{array}{l}\text { 10) Det er et år siden } \\
\text { boka «Bjørn - en } \\
\text { biografi kom ut, og } \\
\text { han innrømmer at det } \\
\text { har vært en vanskelig } \\
\text { tid og en ubehagelig } \\
\text { prosess. }\end{array}$ & $\begin{array}{l}\text { BE har vegret } \\
\text { seg for å fortelle } \\
\text { om den } \\
\text { vanskelige tida, } \\
\text { og journalisten, } \\
\text { Anders } \\
\text { Grønneberg, har } \\
\text { vært pågående } \\
\text { (sim pga. } \\
\text { «innrømmer»). }\end{array}$ & $\begin{array}{l}\text { BE er } \\
\text { beskjeden, og } \\
\text { journalisten } \\
\text { er kompetent. } \\
\text { BE er ydmyk. }\end{array}$ & $\begin{array}{l}\text { Anføringsverbet } \\
\text { «innrømmer» er Dagbladets } \\
\text { retorikk, og innebærer at en } \\
\text { kompetent journalist har fått } \\
\text { BE til å åpne seg. Slik } \\
\text { fortoner også forholdet } \\
\text { mellom BE og Dagbladet seg } \\
\text { mindre som et samarbeid. } \\
\text { Men vi får ikke her vite } \\
\text { hvordan tida har vært } \\
\text { vanskelig, og hvordan } \\
\text { prosessen har vært } \\
\text { ubehagelig. (Anførselstegn } \\
\text { etter «biografi» mangler også } \\
\text { i originalen.) }\end{array}$ \\
\hline $\begin{array}{l}\text { 11) Belastning for } \\
\text { kona (Mellomtittel s. } \\
50 \text { ) }\end{array}$ & & Som sgm 7. & $\begin{array}{l}\text { Hvorfor tenkte ikke BE på det } \\
\text { da han fortalte biografen om } \\
\text { sitt liv? }\end{array}$ \\
\hline $\begin{array}{l}\text { 12) Bjørn Eidsvåg } \\
\text { forteller videre at han }\end{array}$ & $\begin{array}{l}\text { BE er } \\
\text { åpenhjertig. (sim }\end{array}$ & BE er offer. & $\begin{array}{l}\text { Er Dagbladets begjær nå } \\
\text { mindre når Dagbladet }\end{array}$ \\
\hline
\end{tabular}




\begin{tabular}{|c|c|c|c|}
\hline $\begin{array}{l}\text { ble forlegen og sjenert } \\
\text { av mye av det som } \\
\text { kom fram. Mediene } \\
\text { og leserne grep boka } \\
\text { med stort begjær og } \\
\text { kunne lese om blant } \\
\text { annet da han } \\
\text { midlertidig flyttet fra } \\
\text { kona. }\end{array}$ & $\begin{array}{l}\text { pga. «videre»). } \\
\text { BE er beskjeden } \\
\text { (sim pga. } \\
\text { «forlegen og } \\
\text { sjenert»). BE } \\
\text { har sviktet kona } \\
\text { (sim pga. } \\
\text { «midlertidig } \\
\text { flyttet fra»). }\end{array}$ & & $\begin{array}{l}\text { gjenforteller noe av det som } \\
\text { må ha vært vanskelig? } \\
\text { Kanskje det inngår i } \\
\text { promotering av biografien? }\end{array}$ \\
\hline $\begin{array}{l}\text { 13) - Det var } \\
\text { utleverende og ble en } \\
\text { belastning, ikke bare } \\
\text { for meg, men for } \\
\text { familien, venner og } \\
\text { kolleger. }\end{array}$ & & Som sgm 7 . & $\begin{array}{l}\text { Hvorfor skal dette poenget } \\
\text { understrekes så sterkt ved } \\
\text { gjentakelse? Er det grunn til å } \\
\text { tvile på BE, eller må } \\
\text { Dagbladet gjenta for å gi } \\
\text { inntrykk av at oppslaget er en } \\
\text { human touch-historie og ikke } \\
\text { ei platepromotering? Hvordan } \\
\text { ble biografien utleverende og } \\
\text { belastende? }\end{array}$ \\
\hline $\begin{array}{l}\text { 14) - Spesielt kona } \\
\text { følte belastningen } \\
\text { stor, sier Bjørn } \\
\text { Eidsvåg. }\end{array}$ & & Som sgm 7. & \\
\hline $\begin{array}{l}\text { 15) - Jeg har alltid } \\
\text { skjermet og vernet om } \\
\text { familien. Kona syntes } \\
\text { overhodet ikke noe } \\
\text { om bokprosjektet. Det } \\
\text { var mye der det ikke } \\
\text { var hyggelig å bli } \\
\text { minnet om, sier Bjørn } \\
\text { Eidsvåg. }\end{array}$ & & $\begin{array}{l}\text { Som sgm } 7 . \\
\text { BE er en } \\
\text { antihelt. }\end{array}$ & $\begin{array}{l}\text { Hva «mye» var det ikke } \\
\text { hyggelig å bli minnet om? } \\
\text { Hvordan kan vi tro på at BE } \\
\text { er et offer hvis han ikke } \\
\text { dokumenterer? }\end{array}$ \\
\hline 16) Følte seg presset & & Som sgm 5. & $\begin{array}{l}\text { At BE «følte seg» presset, } \\
\text { betyr noe annet enn at han var } \\
\text { presset ( } \operatorname{se} \operatorname{sgm} 2 \text { og } 5) .\end{array}$ \\
\hline $\begin{array}{l}\text { 17) Det var Eidsvåg } \\
\text { selv som tok initiativ } \\
\text { til biografien. Det var } \\
\text { ikke et stort ego eller } \\
\text { ønske om ei bok om } \\
\text { seg selv som fikk ham } \\
\text { til å ta kontakt med } \\
\text { biograf Svendsen. } \\
\text { Han følte seg presset } \\
\text { til å gjøre det. }\end{array}$ & & $\begin{array}{l}\text { BE er } \\
\text { oppriktig og } \\
\text { ikke feig. BE } \\
\text { er beskjeden. } \\
\text { Ellers som } \\
\text { sgm 5. }\end{array}$ & $\begin{array}{l}\text { Dagbladet kobler BE til stort } \\
\text { ego når han må dementere at } \\
\text { det har vært en drivkraft. } \\
\text { Dette svekker BEs etos og } \\
\text { stiller spørsmål ved } \\
\text { Dagbladets vinkling (BE er et } \\
\text { offer). BE fraskrives ansvar } \\
\text { når det står «fikk ham til å ta } \\
\text { kontakt» istedenfor «tok } \\
\text { kontakt». Eksplisitt styrker } \\
\text { Dagbladet her si vinkling av } \\
\text { BE som offer. Implisitt } \\
\text { svekker de imidlertid den }\end{array}$ \\
\hline
\end{tabular}




\begin{tabular}{|c|c|c|c|}
\hline & & & $\begin{array}{l}\text { vinkelen ved å minne om at } \\
\text { egostimulering kan ha vært et } \\
\text { motiv for å gi ut } \\
\text { selvbiografien. Denne doble } \\
\text { forståelsen korresponderer } \\
\text { med tvetydigheten som } \\
\text { oppstår i møtet mellom } \\
\text { eksplisitt og implisitt mening } \\
\text { også ellers i oppslaget. }\end{array}$ \\
\hline $\begin{array}{l}\text { 18) - Det var noen } \\
\text { tvilsomme folk som } \\
\text { ønsket å lage en } \\
\text { biografi om meg. }\end{array}$ & $\begin{array}{l}\text { BE har vært } \\
\text { utsatt for noe } \\
\text { nær en mafia } \\
\text { (sim pga. } \\
\text { «tvilsomme } \\
\text { folk»). (At folka } \\
\text { var tvilsomme, } \\
\text { er semantisk } \\
\text { presupponert.) }\end{array}$ & $\begin{array}{l}\text { BE er et } \\
\text { uskyldig } \\
\text { offer }\end{array}$ & $\begin{array}{l}\text { På hva slags måte tvilsomme? } \\
\text { Hvem er folka, hvor mange } \\
\text { var de, hva var deres motiv, } \\
\text { og hva var deres prosjekt? }\end{array}$ \\
\hline $\begin{array}{l}\text { 19) - Vedkommende } \\
\text { plaget meg og mine } \\
\text { nærmeste - ringte } \\
\text { datteren min og andre } \\
\text { rundt meg for å få ut } \\
\text { opplysninger. Jeg var } \\
\text { under press, og for å } \\
\text { komme } \\
\text { vedkommende i } \\
\text { forkjøpet, tok jeg } \\
\text { initiativ selv. }\end{array}$ & & $\begin{array}{l}\text { BE er ikke } \\
\text { utleverende. } \\
\text { BE er et } \\
\text { offer. BE er } \\
\text { omsorgsfull. } \\
\text { BE er } \\
\text { handlekraftig. }\end{array}$ & $\begin{array}{l}\text { Det er lettere å bakvaske } \\
\text { «vedkommende» enn en som } \\
\text { er navngitt. Hvem er «de } \\
\text { andre»? «Var under press» er } \\
\text { svakere enn Dagbladets } \\
\text { varianter i sgm } 2 \text { og } 5 .\end{array}$ \\
\hline $\begin{array}{l}\text { 20) Eidsvåg har } \\
\text { revurdert sitt syn på } \\
\text { biografier: }\end{array}$ & & $\begin{array}{l}\text { BE lærer av } \\
\text { sine feil } \\
\text { (pim). }\end{array}$ & \\
\hline $\begin{array}{l}\text { 21) - Jeg er ikke } \\
\text { lenger sikker på at det } \\
\text { er riktig at en biografi } \\
\text { skal komme ut før en } \\
\text { er død. }\end{array}$ & & Som sgm 20. & $\begin{array}{l}\text { Det er semantisk } \\
\text { presupponert (pga. «ikke } \\
\text { lenger») at BE godt kan tenke } \\
\text { seg en biografi etter sin død. } \\
\text { Er egoet likevel stort? }\end{array}$ \\
\hline $\begin{array}{l}\text { 22) Ga større } \\
\text { selvinnsikt }\end{array}$ & & $\begin{array}{l}\text { Teologen BE } \\
\text { finner } \\
\text { mening i } \\
\text { motgangen, } \\
\text { og er et } \\
\text { positivt } \\
\text { menneske. }\end{array}$ & BE fokuserer seg selv. \\
\hline $\begin{array}{l}\text { 23) Men boka har } \\
\text { ikke bare gjort livet } \\
\text { vanskelig for den }\end{array}$ & $\begin{array}{l}\text { Som sgm } 22 . \mathrm{BE} \\
\text { er avholdt. }\end{array}$ & & $\begin{array}{l}\text { Perifrasen «den populære } \\
\text { artisten» peker nok mot } \\
\text { opplysninger fra CV-en i }\end{array}$ \\
\hline
\end{tabular}




\begin{tabular}{|c|c|c|c|}
\hline populære artisten. & & & $\begin{array}{l}\text { venstre spalte. (At BE er } \\
\text { populær, er semantisk } \\
\text { presupponert, se sgm 8.) }\end{array}$ \\
\hline $\begin{array}{l}\text { 24) - Boka gjorde } \\
\text { meg klokere, mindre } \\
\text { høy på pæra og ga } \\
\text { meg større } \\
\text { selvinnsikt. Den } \\
\text { gjorde også forholdet } \\
\text { til kona sterkere. }\end{array}$ & & $\begin{array}{l}\text { BE er ærlig } \\
\text { og svartmaler } \\
\text { ikke } \\
\text { situasjonen. } \\
\text { BE er et godt } \\
\text { menneske. }\end{array}$ & $\begin{array}{l}\text { At BE er blitt klokere, mindre } \\
\text { høy på pæra og utstyrt med } \\
\text { større selvinnsikt, er } \\
\text { udokumenterte påstander. Når } \\
\text { forholdet til kona er blitt } \\
\text { sterkere, var det kanskje } \\
\text { likevel bra at biografien ble } \\
\text { gitt ut? Har Dagbladet } \\
\text { overdrevet BEs anger for å få } \\
\text { et bedre oppslag? Er det det } \\
\text { vi kan se spor av i } \\
\text { tvetydigheten som oppstår } \\
\text { mellom bilde og tittel? }\end{array}$ \\
\hline $\begin{array}{l}\text { 25) Bjørn Eidsvåg er } \\
\text { en pengemaskin. Han } \\
\text { sprøyter store penger } \\
\text { inn i sitt selskap } \\
\text { Quint, har full } \\
\text { kontroll over } \\
\text { plateselskapet } \\
\text { Petroleum, og kunne i } \\
\text { fjor heve en lønn på } \\
\text { 5,8 millioner kroner. }\end{array}$ & $\begin{array}{l}\text { BE er opptatt av } \\
\text { penger (sim pga. } \\
\text { «pengemaskin» } \\
\text { etc.). Adjektivet } \\
\text { «full» og } \\
\text { metaforene } \\
\text { «maskin» og } \\
\text { «sprøyter»er } \\
\text { journalist- } \\
\text { hyperboler som } \\
\text { minsker BEs } \\
\text { etos. }\end{array}$ & & $\begin{array}{l}\text { Her er et vendepunkt i } \\
\text { teksten. Nå forlates } \\
\text { biografisekvensen i } \\
\text { hovedartikkelen, og det nye } \\
\text { albumet promoteres. }\end{array}$ \\
\hline $\begin{array}{l}\text { 26) - Jeg ble slått av } \\
\text { Øystein Sunde, men } \\
\text { neste år skal jeg ta } \\
\text { ham, ler Eidsvåg før } \\
\text { han tar en mer } \\
\text { alvorlig tone: }\end{array}$ & $\begin{array}{l}\text { BE er } \\
\text { humoristisk (sim } \\
\text { pga. «ler») og } \\
\text { seriøs (sim pga. } \\
\text { «alvorlig tone»). }\end{array}$ & & $\begin{array}{l}\text { Til tross for den humoristiske } \\
\text { innpakningen virker egoet } \\
\text { stort. }\end{array}$ \\
\hline $\begin{array}{l}\text { 27) - Jeg er glad for å } \\
\text { ha en så god } \\
\text { økonomi. Å tjene } \\
\text { gode penger gjør meg } \\
\text { ikke forlegen, og jeg } \\
\text { håper det fortsetter. } \\
\text { Det gir meg trygghet } \\
\text { og mulighet til fortsatt } \\
\text { å investere i musikken } \\
\text { og lage plater - de er } \\
\text { ikke akkurat billige. }\end{array}$ & $\begin{array}{l}\text { BE arbeider i } \\
\text { kunstens } \\
\text { tjeneste. }\end{array}$ & $\begin{array}{l}\text { BE er } \\
\text { uselvisk. }\end{array}$ & $\begin{array}{l}\text { Men BE framstår også som } \\
\text { selvopptatt. }\end{array}$ \\
\hline
\end{tabular}




\begin{tabular}{|c|c|c|c|}
\hline $\begin{array}{l}\text { 28) Lar seg ikke } \\
\text { mobbe }\end{array}$ & BE er sterk. & & $\begin{array}{l}\text { For leseren spiller } \\
\text { biografisekvensen stadig } \\
\text { med. Er BE blitt mobbet for } \\
\text { noe som nevnes der? }\end{array}$ \\
\hline $\begin{array}{l}\text { 29) Bjørn er involvert } \\
\text { i et hytteprosjekt på } \\
\text { Sørlandet sammen } \\
\text { med blant andre sin } \\
\text { kunstnervenn Kjell } \\
\text { Nupen. I disse } \\
\text { børskrakktider spørs } \\
\text { det ikke om dette kan } \\
\text { bli et tapsprosjekt i } \\
\text { stedet for en lur } \\
\text { investering. }\end{array}$ & & $\begin{array}{l}\text { BE er penge- } \\
\text { spekulant. } \\
\text { BE kan også } \\
\text { bli et } \\
\text { økonomisk } \\
\text { offer. }\end{array}$ & $\begin{array}{l}\text { Journalisten er dus med } \\
\text { intervjuobjektet. Er } \\
\text { promoteringa en } \\
\text { vennetjeneste fra } \\
\text { journalisten? Hvor aktivt er } \\
\text { BE involvert? Tjener han } \\
\text { ikke bare penger for } \\
\text { musikkens skyld? } \\
\text { Journalisten mister etos pga. } \\
\text { syntaksfeil («spørs det ikke } \\
\text { om»). }\end{array}$ \\
\hline $\begin{array}{l}\text { 30) - Tanken har slått } \\
\text { meg, sier Eidsvåg, } \\
\text { som innrømmer at } \\
\text { han er glad i ting - alt } \\
\text { fra sin lap top til hytta } \\
\text { i Skurdalen. }\end{array}$ & $\begin{array}{l}\text { BE er ikke } \\
\text { ufeilbarlig (sim } \\
\text { pga. } \\
\text { «innrømmer»). } \\
\text { BE er materialist } \\
\text { (sim pga. «glad i } \\
\text { ting»). }\end{array}$ & $\begin{array}{l}\text { Journalisten } \\
\text { er kompetent, } \\
\text { som får BE } \\
\text { til å } \\
\text { «innrømme». }\end{array}$ & $\begin{array}{l}\text { Hvor bra er det for teologen å } \\
\text { være materialist? BE er } \\
\text { kanskje ikke bare i kunstens } \\
\text { tjeneste (se sgm 27)? }\end{array}$ \\
\hline $\begin{array}{l}\text { 31) Bjørn Eidsvåg er i } \\
\text { dag ute med sitt } 21 \text {. } \\
\text { album - denne } \\
\text { gangen uten duett } \\
\text { med unge vakre } \\
\text { kvinner. }\end{array}$ & & $\begin{array}{l}\text { BE er ikke } \\
\text { knekt (pim). } \\
\text { BE er en } \\
\text { gammel gris } \\
\text { (pim, hjulpet } \\
\text { fram av den } \\
\text { semantiske } \\
\text { presupposisjo } \\
\text { nen «denne } \\
\text { gangen } \\
\text { uten»). }\end{array}$ & $\begin{array}{l}\text { Er promoteringa av det nye } \\
\text { albumet artikkelens } \\
\text { foranledning? Er } \\
\text { biografisekvensen bare ei } \\
\text { patos-opptakt? }\end{array}$ \\
\hline $\begin{array}{l}\text { 32) Men det er ikke } \\
\text { fordi han føler seg } \\
\text { mobbet av stempelet } \\
\text { som gammel gris. }\end{array}$ & $\begin{array}{l}\text { BE er ikke } \\
\text { lummer (sim } \\
\text { pga. } \\
\text { «stempelet», } \\
\text { som konnoterer } \\
\text { myte og ikke }\end{array}$ & $\begin{array}{l}\text { BE tjener } \\
\text { kunsten. }\end{array}$ & $\begin{array}{l}\text { Når «gammel gris» nevnes, } \\
\text { koples BE til lummerhet. }\end{array}$ \\
\hline
\end{tabular}




\begin{tabular}{|c|c|c|c|}
\hline & $\begin{array}{l}\text { realitet). (At BE } \\
\text { har et slikt } \\
\text { stempel, er } \\
\text { semantisk } \\
\text { presupponert.) }\end{array}$ & & \\
\hline $\begin{array}{l}\text { 33) - Jeg kommer nok } \\
\text { til å gjøre det igjen. } \\
\text { Jeg lar meg ikke } \\
\text { skremme. Jeg blir } \\
\text { forlegen i } \\
\text { duettsituasjoner } \\
\text { samen med kvinner, } \\
\text { sier Eidsvåg, som } \\
\text { forteller at det oppstår } \\
\text { en ertende dynamikk } \\
\text { og en leken stemning } \\
\text { i slike situasjoner. }\end{array}$ & $\begin{array}{l}\text { BE er modig } \\
\text { (sim pga. «lar } \\
\text { meg ikke } \\
\text { skremme»). BE } \\
\text { er ikke frampå } \\
\text { (sim pga. } \\
\text { «forlegen»). BE } \\
\text { liker å flørte } \\
\text { (sim pga. } \\
\text { «ertende» og } \\
\text { «leken»). }\end{array}$ & & $\begin{array}{l}\text { Motstridende karakteristikker } \\
\text { («forlegen», «ertende» og } \\
\text { «leken») gjør det uklart om } \\
\text { BE er en gammel gris. }\end{array}$ \\
\hline $\begin{array}{l}\text { 34) Livets gode } \\
\text { krefter }\end{array}$ & & BE er positiv. & \\
\hline $\begin{array}{l}\text { 35) «Pust» er den } \\
\text { siste plata i en trilogi } \\
\text { om livets store } \\
\text { spørsmål. }\end{array}$ & & $\begin{array}{l}\text { BE er en } \\
\text { tenker. }\end{array}$ & $\begin{array}{l}\text { Denne sekvensen om BEs } \\
\text { nye CD kommer tilforlatelig, } \\
\text { men uten at det henger } \\
\text { sammen med resten av } \\
\text { teksten. Det er uklart for } \\
\text { leseren hva det har med saka } \\
\text { å gjøre - hvis man ikke har } \\
\text { sett og godtatt at saka er et } \\
\text { påskudd til å snakke om CD- } \\
\text { en, eller at CD-en er et } \\
\text { påskudd til å snakke om BEs } \\
\text { privatliv. }\end{array}$ \\
\hline $\begin{array}{l}\text { 36) - «Tålt» } \\
\text { omhandler mitt } \\
\text { forhold til } \\
\text { kjærligheten i voksen } \\
\text { alder. På «Nåde» er } \\
\text { temaet forholdet til } \\
\text { døden. På «Pust» } \\
\text { ønsker jeg å heie på } \\
\text { livets gode krefter, } \\
\text { sier Bjørn Eidsvåg, } \\
\text { som nyter } \\
\text { opplevelsene }\end{array}$ & $\begin{array}{l}\text { BE har sunne } \\
\text { interesser (sim, } \\
\text { hjulpet fram av } \\
\text { semantisk } \\
\text { presupposisjon i } \\
\text { «opplevelsene } \\
{[\ldots] \text { gir ham»). }}\end{array}$ & $\begin{array}{l}\text { BE mener } \\
\text { noe med } \\
\text { kunsten sin. }\end{array}$ & $\begin{array}{l}\text { Opplysningene om BEs } \\
\text { interesse for friluftsliv virker } \\
\text { malplassert, for i denne delen } \\
\text { av teksten handler det bare } \\
\text { om den nye CD-en. Er } \\
\text { opplysningene tatt med for å } \\
\text { beholde fokuset på person } \\
\text { framfor sak, slik at kontrasten } \\
\text { mellom de to sekvensene ikke }\end{array}$ \\
\hline
\end{tabular}




\begin{tabular}{|c|c|c|c|}
\hline $\begin{array}{l}\text { fjellvandring og } \\
\text { naturen gir ham. }\end{array}$ & & & skal bli for stor? \\
\hline $\begin{array}{l}\text { 37) Albumet er spilt } \\
\text { inn i Sørlands-naust } \\
\text { på et Ny-Hellesund, } \\
\text { sammen med blant } \\
\text { annet legenden Georg } \\
\text { Riedel. }\end{array}$ & $\begin{array}{l}\text { BE er sjøl meget } \\
\text { anerkjent (sim } \\
\text { pga. } \\
\text { «legenden»). (At } \\
\text { Riedel er en } \\
\text { legende, blir } \\
\text { semantisk } \\
\text { presupponert.) }\end{array}$ & $\begin{array}{l}\text { Journalisten } \\
\text { mister etos } \\
\text { pga. } \\
\text { skrivefeil. }\end{array}$ & $\begin{array}{l}\text { Det er en overflødig artikkel } \\
\text { foran stedsnavnet Ny } \\
\text { Hellesund i tillegg til en } \\
\text { subjektfeil: Riedel er ikke } \\
\text { spilt inn; han har spilt inn. }\end{array}$ \\
\hline $\begin{array}{l}\text { 38) - Det var magisk } \\
\text { da han pakket ut } \\
\text { bassen. Riedel er } \\
\text { mannen som skrev } \\
\text { låter sammen med } \\
\text { Cornelis Wreesvjik og } \\
\text { spilte inn plater med } \\
\text { Jan Johansson. Da } \\
\text { han dro, sa han at } \\
\text { dette var hans mest } \\
\text { spektakulære } \\
\text { innspilling. Han ville } \\
\text { ikke engang ha betalt, } \\
\text { sier Eidsvåg, som } \\
\text { selvsagt sendte ham } \\
\text { sin velfortjente hyre. }\end{array}$ & $\begin{array}{l}\text { BE gjør opp for } \\
\text { seg (sim, fordi } \\
\text { BE betalte). BE } \\
\text { har en god } \\
\text { moral (sim pga. } \\
\text { «selvsagt»). }\end{array}$ & $\begin{array}{l}\text { BE er like } \\
\text { stor som } \\
\text { Riedel. BE } \\
\text { har stort ego. } \\
\text { Journalisten } \\
\text { mister igjen } \\
\text { ethos pga. } \\
\text { skrivefeil } \\
\text { (hans/sin- } \\
\text { feil). }\end{array}$ & $\begin{array}{l}\text { Også i } \\
\text { promoteringssekvensen } \\
\text { flettes det inn ei bredspektret } \\
\text { etos-bygging: BE forteller om } \\
\text { sin kompetanse og } \\
\text { journalisten om hans gode } \\
\text { moral. Men dette går på } \\
\text { bekostning av journalistens } \\
\text { etos fordi han så tydelig } \\
\text { spiller på lag med kilden. BEs } \\
\text { selvskryt motsier sgm } 17 \text { og } \\
24 .\end{array}$ \\
\hline $\begin{array}{l}\text { 39) - Presset ikke } \\
\text { Eidsvåg (Tittel } \\
\text { undersak) }\end{array}$ & & $\begin{array}{l}\text { BE er en } \\
\text { løgner. }\end{array}$ & \\
\hline $\begin{array}{l}\text { 40) Personen Bjørn } \\
\text { Eidsvåg refererer til, } \\
\text { tilbakeviser } \\
\text { påstandene om at } \\
\text { artisten ble presset. }\end{array}$ & & $\begin{array}{l}\text { Journalisten } \\
\text { er } \\
\text { hensynsfull } \\
\text { ved å ikke } \\
\text { navngi. } \\
\text { Dagbladet er } \\
\text { aktverdig av } \\
\text { samme } \\
\text { grunn. } \\
\text { Dagbladet } \\
\text { styrker sin } \\
\text { etos ved å } \\
\text { slippe til et } \\
\text { motsvar. }\end{array}$ & $\begin{array}{l}\text { I nyhetsartikler er det vanlig å } \\
\text { først slippe til et «motsvar» i } \\
\text { ei undersak. Likevel er det en } \\
\text { underlig balanse mellom de } \\
\text { to sidene i saka. Det er også } \\
\text { underlig at Dagbladet slår } \\
\text { opp BEs versjon som et } \\
\text { faktum jfr. sgm } 5 \text {. }\end{array}$ \\
\hline
\end{tabular}




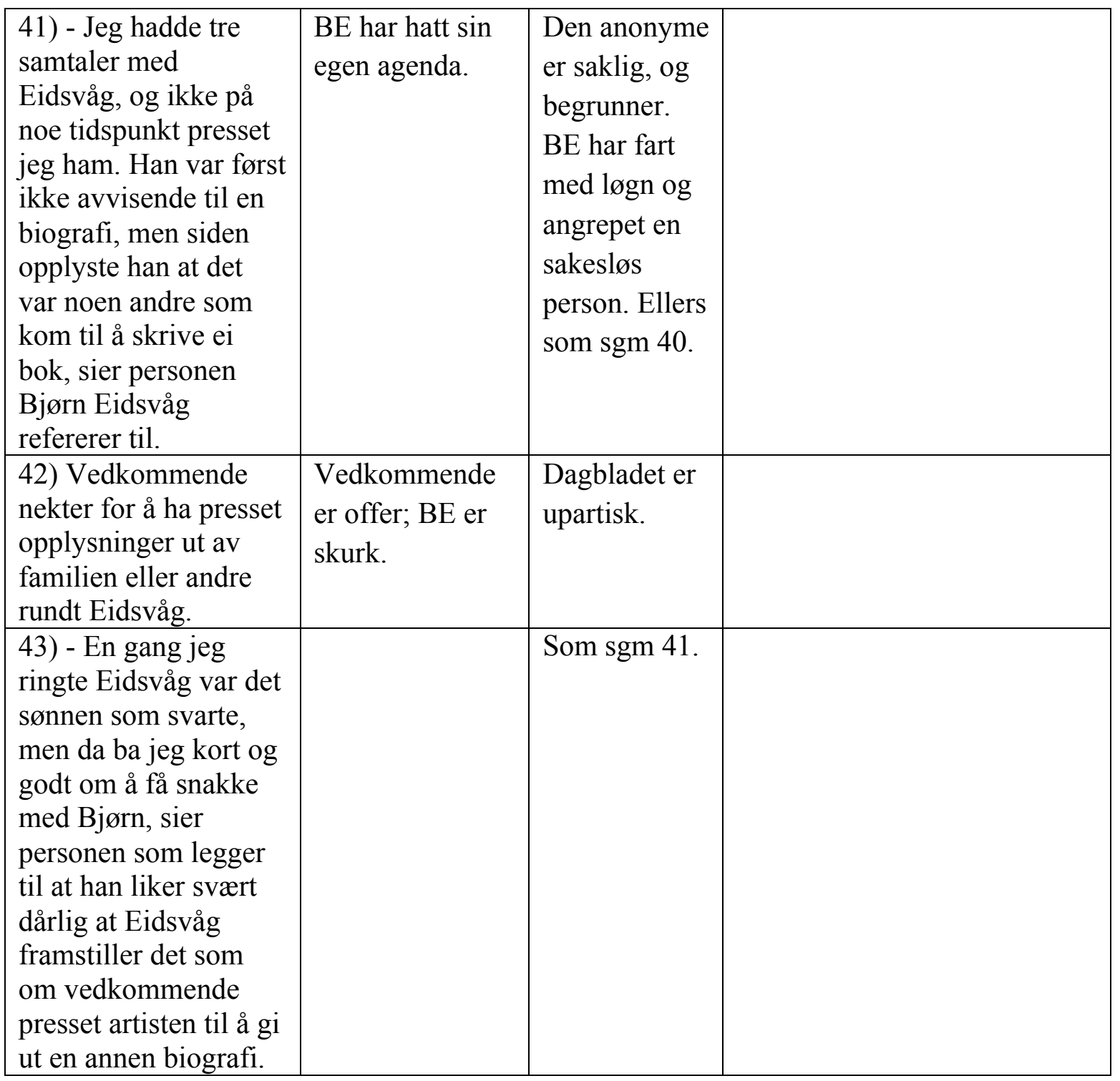

\section{Autentisk eller iscenesatt?}

Implikaturer blir ikke begrunnet, men presenteres som noe det er enighet om. Og som vi ser av de to midterste kolonnene i segmenteringsskjemaet, er det nettopp det diskutable og uavklarte som kommuniseres gjennom implikaturene. Dette skaper mistro til Dagbladet og Eidsvåg. Slik vi viser i kommentarene i høyre kolonne, kan man undre seg over hvorfor saka i det hele tatt kommer på trykk, og hvorfor Eidsvåg og Dagbladet spiller på lag på denne måten.

Sprikende implikaturer avdekker en mangelfull koherens i teksten som gjør det mulig å tolke etosetableringa som lite vellykket strategisk sett. Spriket ligger til grunn for problematiseringene $\mathrm{i}$ høyre kolonne i analyseskjemaet.

Den implisitte etosbygginga foregår både gjennom semantiske og pragmatiske implikaturer. De semantiske implikaturene vil være de samme når en kilde ytrer seg, som når 
kilden blir sitert av andre. Ytringa «Det var utleverende og ble en belastning, ikke bare for meg, men for familien, venner og kolleger» innebærer at Eidsvåg er familiekjær. Denne implikaturen vil være en del av utsagnet både når setningen blir ytret av Eidsvåg, og når den blir sitert i Dagbladet. Den egenskapen ved semantiske implikaturer at de innebærer det samme når setningen blir ytret av en kilde som når kilden blir sitert, forsterker symbiosen mellom kilde og journalist - ved at begge parter dermed går god for innebæringa.

Både samfunnet, kulturen og den verbalspråklige teksten som omgir et utsagn, vil bidra til hvilke pragmatiske implikaturer vi vil lese ut av ytringa. Når en avis trykker et sitat fra en kilde, vil avisa derfor i noen grad kunne påvirke hvilke pragmatiske implikaturer vi vil lese i ytringa. I Dagbladets artikkel innebærer ytringa «Det var utleverende og ble en belastning, ikke bare for meg, men for familien, venner og kolleger» at Eidsvåg er et offer, siden opplysningene fra tittelen om at Eidsvåg ble presset, kombineres med opplysningene om at han gjorde noe som ble belastende for ham selv og familien. Hvis tittelen hadde vært en annen, kunne implikaturen i det nevnte sitatet ha endret seg. Helt til slutt i artikkelen blir personen som Eidsvåg refererer til, intervjuet. Han benekter påstanden fra tittelen, så vi kan godt tenke oss en annen tittel på artikkelen, for eksempel med en opplysning om at Eidsvåg tok initiativ til en biografi (slik han selv sier han gjorde). Da ville et pragmatisk implikatur i ytringa «Det var utleverende og ble en belastning, ikke bare for meg, men for familien, venner og kolleger» blitt at Eidsvåg er en angrende synder, og ikke at han er et offer.

Det er ingen ny innsikt at ei ytring endrer betydning når den settes $\mathrm{i}$ en annen sammenheng, men det vi oppnår ved å skille mellom semantisk og pragmatisk implikatur, er at vi i større grad kan se hvordan de to stemmene i teksten (Eidsvågs og Dagladets) virker sammen. Problematiseringa i høyre kolonne viser hvordan Dagbladet konsekvent bygger opp Eidsvågs etos, selv om de fint kunne valgt noe annet uten å gå på akkord med presseetiske idealer.

Segmenteringsanalysen av etos-implikaturer viste noe av det vi med utgangspunkt i teksten og konteksten kan utlede om Eidsvåg. Det vi utleder, er oppsummert i en stor mengde fyndord. Eidsvåg er et godt menneske, trofast, familiekjær, seriøs, produktiv, populær, avholdt, beskjeden og uselvisk. Men han er også kontrastfylt og disharmonisk. Mange av disse karakteristikkene ville ha virket platte på trykk. Ei oppramsing av adjektiver ville vært trettende og lite original, og den ville ha brutt med det journalistiske idealet "show, don't tell". Men den ville også ha gitt inntrykk av at journalisten ukritisk hyller Eidsvåg. Når vi selv må utlede hvilke egenskaper Eidsvåg har, er det lettere å akseptere det som sant; det er noe vi har kommet fram til selv.

For noen lesere vil imidlertid bildet slå sprekker. Et vesentlig autentisitetskrav er å ikke framstå som iscenesatt (Johansen 2002; Kjeldsen 2004, s. 121). I førstesideoppslaget og i bildet fant vi en tvetydighet. Tvetydigheten kan så en mistanke om at dette ikke er så ektefølt som det virker. Denne tvetydigheten preger også artikkelen.

Mange av tvetydighetene, motsigelsene og uklarhetene er knyttet til biografisekvensen. Biografisekvensen inngår i avisas patosretorikk for å etablere sympati for Eidsvåg. Men hvorfor minne om fjorårets biografi når den har vært så belastende, og hvorfor klage over belastningen på kona når både hun og Eidsvåg er blitt styrket av erfaringene? 
Eidsvåg er lite konkret når han skal beskrive belastningene. Mye mer konkret er han når han får fortelle om det nye albumet. Eidsvåg er også lite konsis når han skal begrunne presset han skal ha følt. Den anonymiserte skurken i fortellinga presenterer en mer detaljert versjon av hendelsesforløpet, og lykkes godt i å avdramatisere - nettopp fordi Eidsvåg er vag.

Ei sak er at Eidsvåg kan ha brukt biografisekvensen for å promotere det nye albumet; ei anna sak er at Dagbladet har latt ham gjøre det for å få et kjendisoppslag. Mellom biografisekvensen og promoteringssekvensen er det dårlig sammenheng. Bedre er sammenhengen mellom promoteringssekvensen og en anmeldelse av det omtalte albumet, som er plassert sammen med nyhetsartikkelen. Toppoppslag på førstesida og to fulle sider inne i Dagbladets lørdagsutgave er bra utbytte av åpenhjertig anger når en skal promotere et nytt album. Men hvordan er Dagbladets utbytte? Det kan godt være journalistisk motivert å skrive om at en av Norges mestselgende artister gir ut ny CD. Slik bryter ikke oppslaget med Tekstreklameplakaten (Norsk Presseforbund 2007). Det er mer tvilsomt hvor fritt og uavhengig Dagbladet har opptrådt overfor kilden sin. Vær Varsom-plakatens punkt 2.2 lyder: «Den enkelte redaksjon og den enkelte medarbeider må verne om sin integritet og troverdighet for å kunne opptre fritt og uavhengig i forhold til personer eller grupper som av ideologiske, økonomiske eller andre grunner vil øve innflytelse på det redaksjonelle innhold» (Norsk Presseforbund 2008). Dagbladet befinner seg i et etisk grenseland når de går i tospann med en kjendis om å bygge hans etos. Samtidig spiller de høyt med sin egen etos når de systematisk promoterer Eidsvågs CD-utgivelse under dekke av å produsere en kulturnyhet.

\section{Anmeldelsen}

At anmeldelsen står sammen med nyheten, er trolig gunstig for Eidsvåg, som ønsker publisitet. Dermed kan Dagbladets etos svekkes. Men det kan også hende Dagbladets etos restitueres ved at avisa $\mathrm{i}$ anmeldelsen kan presentere et uavhengig syn og slik vise integritet. Avisa viser åpent at det er en sammenheng mellom artiklene slik de er satt opp. Artiklene representerer ulike sjangrer. Som det framgikk under redegjørelsen for sjangerbegrepet, er sjangrer ulike handlinger knytta til ulike sosiale aktiviteter (Miller 2001, s. 20; Ledin 1996, s. 42). Det kan derfor hende etosetableringa er ulik i nyheten og anmeldelsen. Eventuelle slike forskjeller, og hva de innebærer både som en belysning av den retoriske situasjonen og for en forståelse av sjangersærpreg og sjangerforskjeller, vil framgå av en segmenteringsanalyse av etosetablering ved semantiske og pragmatiske implikaturer i anmeldelsen som også inngår i caset:

\begin{tabular}{|l|l|l|l|}
\hline Segmentert tekst & $\begin{array}{l}\text { Semantisk etos- } \\
\text { implikatur (sim) }\end{array}$ & $\begin{array}{l}\text { Pragmatisk } \\
\text { etos- } \\
\text { implikatur } \\
\text { (pim) }\end{array}$ & Problematisering \\
\hline 1) Noen friske pust & & $\begin{array}{l}\text { BE har laget ei } \\
\text { middels bra } \\
\text { plate. } \\
\text { Anmelderen }\end{array}$ & \\
\hline
\end{tabular}




\begin{tabular}{|c|c|c|c|}
\hline & & $\begin{array}{l}\text { (A) er vittig } \\
\text { (han lager en } \\
\text { allusjon til } \\
\text { platas tittel). }\end{array}$ & \\
\hline $\begin{array}{l}\text { 2) At Bjørn Eidsvåg } \\
\text { selger mange plater } \\
\text { er like sikkert som at } \\
\text { han nekter å bryte } \\
\text { med sin egen } \\
\text { suksessformel. }\end{array}$ & $\begin{array}{l}\text { BE er lite endringsvillig } \\
\text { (pga. «nekter»). } \\
\text { For BE er det viktig å } \\
\text { tjene mange penger. }\end{array}$ & $\begin{array}{l}\text { BE er en } \\
\text { suksessrik } \\
\text { artist. } \\
\text { BE er } \\
\text { forutsigbar. }\end{array}$ & $\begin{array}{l}\text { Antyder A at BE burde } \\
\text { ha brutt med sin egen } \\
\text { «suksessformel»? I så } \\
\text { fall markerer han } \\
\text { allerede i innledningen } \\
\text { en avstand til artisten og } \\
\text { musikken. }\end{array}$ \\
\hline $\begin{array}{l}\text { 3) Det preger også } \\
\text { «Pust». }\end{array}$ & & $\begin{array}{l}\text { «Pust» er lite } \\
\text { original. A har } \\
\text { god innsikt i } \\
\text { BEs } \\
\text { produksjon. }\end{array}$ & $\begin{array}{l}\text { A bygger sin egen etos } \\
\text { ved å vise kompetanse. }\end{array}$ \\
\hline \multicolumn{4}{|l|}{$\begin{array}{l}\text { 4) Bjørn Eidsvåg } \\
\text { «Pust» } \\
\text { (Petroleum Records/ } \\
\text { Sony BMG) }\end{array}$} \\
\hline $\begin{array}{l}\text { 5) Nesten irriterende } \\
\text { på det jevne. }\end{array}$ & BE er kjedelig. & $\begin{array}{l}\text { A er ærlig og } \\
\text { direkte. } \\
\text { A tar sin } \\
\text { kompetanse } \\
\text { for gitt (ved } \\
\text { evaluativ } \\
\text { språkhandling } \\
\text { [SH]). }\end{array}$ & $\begin{array}{l}\text { Karakteristikken «på det } \\
\text { jevne» kan vise både til } \\
\text { BE, som ikke har } \\
\text { utviklet seg, og til plata, } \\
\text { som er uten } \\
\text { overraskelser. }\end{array}$ \\
\hline $\begin{array}{l}\text { 6) CD: Bjørn } \\
\text { Eidsvåg har byttet ut } \\
\text { deler av bandet og } \\
\text { overlatt } \\
\text { produksjonen til sin } \\
\text { faste trommis } \\
\text { Anders Engen (som } \\
\text { har byttet ut seg sjøl } \\
\text { med Madrugadas } \\
\text { Erland Dahlen, og i } \\
\text { stedet spiller } \\
\text { perkusjon). }\end{array}$ & $\begin{array}{l}\text { BE har nære } \\
\text { samarbeidspartnere som } \\
\text { han stoler på (han har } \\
\text { overlatt produksjonen til } \\
\text { Anders Engen). }\end{array}$ & $\begin{array}{l}\text { BE er en } \\
\text { mektig artist } \\
\text { som fritt kan } \\
\text { velge hvem } \\
\text { han vil } \\
\text { samarbeide } \\
\text { med. } \\
\text { A er godt } \\
\text { informert } \\
\text { (konstativ SH). }\end{array}$ & $\begin{array}{l}\text { Her er det interessant } \\
\text { agens-bruk. Bandet er } \\
\text { ikke byttet ut, } B E \text { har } \\
\text { byttet det ut. Det er altså } \\
\text { BE som er årsaken til } \\
\text { endringene. Likevel } \\
\text { skriver A at produsenten } \\
\text { Anders Engen byttet ut } \\
\text { seg selv med en annen. } \\
\text { Har BE likevel ikke full } \\
\text { kontroll, eller er det A } \\
\text { som er upresis? }\end{array}$ \\
\hline $\begin{array}{l}\text { 7) Det er likevel } \\
\text { ikke snakk om de } \\
\text { store } \\
\text { kvantesprangene, } \\
\text { verken musikalsk } \\
\text { eller tekstlig, når } \\
\text { han nå avslutter } \\
\text { trilogien som startet }\end{array}$ & $\begin{array}{l}\text { BE vil ikke fornye seg. } \\
\text { A synes BE burde ha } \\
\text { fornyet seg (sim pga. } \\
\text { «likevel»). }\end{array}$ & $\begin{array}{l}\text { BE står på } \\
\text { stedet hvil. BE } \\
\text { er en ambisiøs } \\
\text { artist (han gir } \\
\text { ut en trilogi). } \\
\text { A tar sin } \\
\text { kompetanse } \\
\text { for gitt }\end{array}$ & $\begin{array}{l}\text { Som i segment } 1 \\
\text { antyder A at han ikke } \\
\text { liker BEs musikk. } \\
\text { Hadde «likevel» vært } \\
\text { byttet ut med «men», } \\
\text { ville den semantiske } \\
\text { implikaturen blitt en } \\
\text { annen. }\end{array}$ \\
\hline
\end{tabular}




\begin{tabular}{|c|c|c|c|}
\hline $\begin{array}{l}\text { med «Tålt» og } \\
\text { «Nåde». }\end{array}$ & & (evaluativ SH). & \\
\hline 8) «Country-Bjørn» & $\begin{array}{l}\text { BE spiller country- } \\
\text { musikk. }\end{array}$ & $\begin{array}{l}\text { BE er enkel og } \\
\text { sjablongpreget. } \\
\text { A er } \\
\text { nedlatende. }\end{array}$ & $\begin{array}{l}\text { Konteksten tilsier at } \\
\text { «Country-Bjørn» ikke } \\
\text { er et kjælenavn her. }\end{array}$ \\
\hline $\begin{array}{l}\text { 9) Med unntak av } \\
\text { Geir Sundstøls } \\
\text { gitarer, som med sin } \\
\text { smakfulle pedal } \\
\text { steel på fire spor } \\
\text { (sic!) introduserer } \\
\text { herved (sic!) } \\
\text { «Country-Bjørn», og } \\
\text { David Wallumrøds } \\
\text { tangenter, ikke } \\
\text { minst på «Blikket } \\
\text { ditt» og «For seint», } \\
\text { holder Eidsvåg seg i } \\
\text { trygge, forutsigbare } \\
\text { og godt } \\
\text { kvalitetssikrede } \\
\text { spor. }\end{array}$ & $\begin{array}{l}\text { BE burde endret seg. } \\
\text { (sim pga. av «trygge, } \\
\text { forutsigbare og godt } \\
\text { kvalitetssikrede spor»). }\end{array}$ & $\begin{array}{l}\text { BE er ikke } \\
\text { eksperimentell. } \\
\text { A viser } \\
\text { musikkfaglig } \\
\text { kompetanse, } \\
\text { men svekker } \\
\text { sin etos ved } \\
\text { syntaksslurv. }\end{array}$ & $\begin{array}{l}\text { Hvordan kan A rose de } \\
\text { nye bandmedlemmene, } \\
\text { men ikke BE som har } \\
\text { valgt dem ut? A liker } \\
\text { ikke BEs musikk; hadde } \\
\text { han gjort det, kunne han } \\
\text { f. eks ha valgt å skrive } \\
\text { «BE leverer varene». } \\
\text { Syntaksslurvet består i } \\
\text { at A har skrevet «fire } \\
\text { spor» istedenfor «spor } \\
\text { fire». Dessuten passer } \\
\text { ikke «herved». }\end{array}$ \\
\hline $\begin{array}{l}\text { 10) Det er ikke til å } \\
\text { komme fra at han er } \\
\text { blitt ganske flink til } \\
\text { å gjenta seg sjøl, og } \\
\text { det er de nevnte } \\
\text { herrer som skaper de } \\
\text { små tilløp til magi } \\
\text { som kan spores på } \\
\text { plata. }\end{array}$ & $\begin{array}{l}\text { A er ironisk (pga. } \\
\text { «flink») og framstår } \\
\text { derved som mindre } \\
\text { saklig. } \\
\text { A har imidlertid prøvd å } \\
\text { se etter variasjon (pga. } \\
\text { «det er ikke til å komme } \\
\text { bort fra»). }\end{array}$ & $\begin{array}{l}\text { BE står på } \\
\text { stedet hvil. } \\
\text { A framstår } \\
\text { som en mobber } \\
\text { ved å gjenta } \\
\text { det samme } \\
\text { poenget. }\end{array}$ & $\begin{array}{l}\text { Til tross for at A skriver } \\
\text { at det er BE selv som } \\
\text { har valgt å bytte ut deler } \\
\text { av bandet, så er det } \\
\text { musikerne og ikke BE } \\
\text { som får æren for } \\
\text { forandringen. } \\
\text { Når A mobber BE ved å } \\
\text { gjenta poenget, kan han } \\
\text { framstå som } \\
\text { usympatisk, mens BE } \\
\text { kan få mer sympati. }\end{array}$ \\
\hline $\begin{array}{l}\text { 11) Det er gjort en } \\
\text { del vellykte grep, } \\
\text { men jeg tror Eidsvåg } \\
\text { hadde tålt å bli } \\
\text { strukket en god del } \\
\text { lenger. }\end{array}$ & $\begin{array}{l}\text { BE er ikke kunstnerisk } \\
\text { ambisiøs og kan ikke stå } \\
\text { på egne bein. Det er noen } \\
\text { andre enn Eidsvåg som } \\
\text { har æren for at plata er } \\
\text { bra (pga. den agensløse } \\
\text { setningen «det er } \\
\text { gjort...» og fordi BE er } \\
\text { logisk objekt for «bli } \\
\text { strukket»). }\end{array}$ & $\begin{array}{l}\text { A framstår } \\
\text { ikke som } \\
\text { forutinntatt, } \\
\text { siden han tror } \\
\text { BE har større } \\
\text { potensial. } \\
\text { A tar sin } \\
\text { kompetanse } \\
\text { for gitt } \\
\text { (evaluativ } \mathrm{SH} \text { ). }\end{array}$ & $\begin{array}{l}\text { Igjen framstilles BE } \\
\text { som en } \\
\text { handlingslammet } \\
\text { deltager på sin egen } \\
\text { plate. Dette er første og } \\
\text { eneste gang A bruker } \\
\text { «jeg». Det er også det } \\
\text { mest eksplisitte } \\
\text { uttrykket for at A ikke } \\
\text { er særlig begeistret for } \\
\text { BEs tradisjonelle } \\
\text { musikk. }\end{array}$ \\
\hline
\end{tabular}




\begin{tabular}{|c|c|c|c|}
\hline 12) Ingen duett & & & \\
\hline $\begin{array}{l}\text { 13) I motsetning til } \\
\text { de to forrige } \\
\text { albumene i trilogien, } \\
\text { har ikke dette en søt } \\
\text { duett som kan virke } \\
\text { som et lokomotiv } \\
\text { for platesalget. }\end{array}$ & $\begin{array}{l}\text { BE kan spille på } \\
\text { romantikk. }\end{array}$ & $\begin{array}{l}\text { Albumet er på } \\
\text { alle måter } \\
\text { mislykket. } \\
\text { A viser } \\
\text { kompetanse. }\end{array}$ & $\begin{array}{l}\text { I sgm. 2, 3, 7, } 9 \text { og } 10 \\
\text { framholdes at BE ikke } \\
\text { fornyer seg. I sgm. } 13 \\
\text { framholdes at han ikke } \\
\text { gjentar seg. }\end{array}$ \\
\hline $\begin{array}{l}\text { 14) Men han trenger } \\
\text { det neppe. }\end{array}$ & & $\begin{array}{l}\text { BE er populær } \\
\text { uansett. } \\
\text { A viser tvisyn } \\
\text { og framstår } \\
\text { som åpen og } \\
\text { kompetent } \\
\text { (pga. } \\
\text { funksjonsordet } \\
\text { «men»). }\end{array}$ & $\begin{array}{l}\text { Det oppstår en kontrast } \\
\text { mellom dette og } \\
\text { foregående segment, } \\
\text { siden det forrige var } \\
\text { agensløst. Igjen framstår } \\
\text { BE som en som ikke } \\
\text { handler. Det var ikke } \\
\text { han som valgte å ikke ta } \\
\text { med duetten. }\end{array}$ \\
\hline $\begin{array}{l}\text { 15) «E du den du e» } \\
\text { er fengende nok, og } \\
\text { det er lett å forstå at } \\
\text { den er valgt som } \\
\text { singel. }\end{array}$ & $\begin{array}{l}\text { BE har kvaliteter som } \\
\text { artist. }\end{array}$ & $\begin{array}{l}\text { A er tvisynt og } \\
\text { ikke } \\
\text { forutinntatt. } \\
\text { A tar sin } \\
\text { kompetanse } \\
\text { for gitt } \\
\text { (evaluativ } \mathrm{SH} \text { ). }\end{array}$ & $\begin{array}{l}\text { Her vurderer A den } \\
\text { kommersielle og } \\
\text { økonomiske verdien av } \\
\text { plata, ikke den } \\
\text { kunstneriske. }\end{array}$ \\
\hline $\begin{array}{l}\text { 16) Tittellåta og } \\
\text { avsluttende «Sett } \\
\text { at», platas beste } \\
\text { spor, kunne også } \\
\text { gjort nytte som det. } \\
\text { Det bærer bud om } \\
\text { hva denne plata } \\
\text { kunne blitt. }\end{array}$ & $\begin{array}{l}\text { BE har ikke realisert sitt } \\
\text { potensial. }\end{array}$ & $\begin{array}{l}\text { A har god } \\
\text { vurderings- } \\
\text { evne. }\end{array}$ & \\
\hline $\begin{array}{l}\text { 17) Med «Pust» } \\
\text { uttaler Eidsvåg at } \\
\text { han ønsker «å heie } \\
\text { på livets gode } \\
\text { krefter», men så } \\
\text { veldig gjennomført } \\
\text { er det ikke. }\end{array}$ & BE er inkonsekvent. & $\begin{array}{l}\text { A tar sin } \\
\text { kompetanse } \\
\text { for gitt } \\
\text { (evaluativ } \mathrm{SH} \text { ). }\end{array}$ & $\begin{array}{l}\text { Det er uklart om sitatet } \\
\text { er hentet fra plata eller } \\
\text { fra intervjuet. Slik er det } \\
\text { uklart om det er BEs } \\
\text { etos eller BEs etos på } \\
\text { plata som kritiseres. }\end{array}$ \\
\hline $\begin{array}{l}\text { 18) Her er mye } \\
\text { kjærlighet og } \\
\text { relasjoner mellom } \\
\text { han og henne, men } \\
\text { også store doser } \\
\text { anger, moralsk } \\
\text { forargelse, politisk } \\
\text { og religiøs }\end{array}$ & $\begin{array}{l}\text { BE tematiserer viktige } \\
\text { dimensjoner i livet. }\end{array}$ & $\begin{array}{l}\text { BE er åpen og } \\
\text { bruker } \\
\text { selvbiografiske } \\
\text { elementer. } \\
\text { A er velvillig } \\
\text { og viser } \\
\text { kompetanse. }\end{array}$ & $\begin{array}{l}\text { Tema-parafraseringen } \\
\text { viser at det er en } \\
\text { sammenheng mellom } \\
\text { det BE uttalte i } \\
\text { intervjuet og innholdet } \\
\text { på plata. Verken } \\
\text { anmelderen eller } \\
\text { journalisten peker på }\end{array}$ \\
\hline
\end{tabular}




\begin{tabular}{|c|c|c|c|}
\hline $\begin{array}{l}\text { indignasjon } \\
\text { («Jerusalem») og } \\
\text { framfor alt tungt } \\
\text { opparbeidet } \\
\text { livserfaring. }\end{array}$ & & & $\begin{array}{l}\text { dette. Det styrker } \\
\text { Dagbladets etos at } \\
\text { anmeldelsen virker } \\
\text { skrevet uavhengig av } \\
\text { intervjuet med BE. }\end{array}$ \\
\hline $\begin{array}{l}\text { 19) «Svart måne» er } \\
\text { en besk } \\
\text { virkelighetsbeskrivel } \\
\text { se signert } \\
\text { Svovelpredikant- } \\
\text { Eidsvåg: }\end{array}$ & $\begin{array}{l}\text { BE har opplevd vonde } \\
\text { ting (sim pga. } \\
\text { «virkelighetsbeskrivelse» } \\
\text { ). } \\
\text { BE er en misantropisk } \\
\text { forkynner (sim pga. } \\
\text { «Svovelpredikant»). }\end{array}$ & $\begin{array}{l}\text { A mobber BE } \\
\text { ved kallenavn. } \\
\text { A tar sin } \\
\text { kompetanse } \\
\text { for gitt } \\
\text { (evaluativ } \mathrm{SH} \text { ). }\end{array}$ & $\begin{array}{l}\text { Troverdigheten i den } \\
\text { semantiske BE- } \\
\text { implikaturen forsterkes } \\
\text { av «tungt opparbeidet } \\
\text { livserfaring». }\end{array}$ \\
\hline $\begin{array}{l}\text { 20) Lucifer sko me } \\
\text { aldri ha kysst / men } \\
\text { me gjor det, og det } \\
\text { med grådig lyst (..) } \\
\text { Me forgifta brystet } \\
\text { som amma oss / og } \\
\text { hadd ikkje vett te å } \\
\text { skamma oss / me } \\
\text { henga oss te det som } \\
\text { bryte ner / nå e } \\
\text { apokalypsen her. }\end{array}$ & $\begin{array}{l}\text { BE skriver og synger på } \\
\text { dialekt. }\end{array}$ & $\begin{array}{l}\text { A er ryddig og } \\
\text { belegger } \\
\text { vurderingene } \\
\text { sine med } \\
\text { sitater. }\end{array}$ & \\
\hline \multicolumn{4}{|l|}{ 21) Banalt } \\
\hline $\begin{array}{l}\text { 22) Vi møter en } \\
\text { oppriktig og sårbar } \\
\text { Eidsvåg, men også } \\
\text { Pludre-Eidsvåg. }\end{array}$ & $\begin{array}{l}\text { BE er ærlig og personlig, } \\
\text { men også uvesentlig. }\end{array}$ & $\begin{array}{l}\text { A mobber BE } \\
\text { ved kallenavn } \\
\text { (pim fordi } \\
\text { poenget ikke er } \\
\text { hva } \\
\text { kallenavnet } \\
\text { semantisk } \\
\text { betyr, men hva } \\
\text { det innebærer } \\
\text { pragmatisk). } \\
\text { A tar sin } \\
\text { kompetanse } \\
\text { for gitt } \\
\text { (evaluativ SH). }\end{array}$ & $\begin{array}{l}\text { Det kan virke som om } \\
\text { anmelderen nå skal } \\
\text { snakke om det han } \\
\text { kaller «Pludre- } \\
\text { Eidsvåg», men det er } \\
\text { uklart om det er det han } \\
\text { gjør. }\end{array}$ \\
\hline $\begin{array}{l}\text { 23) Han er en solid } \\
\text { ordsnekker, men } \\
\text { ikke mer enn at han } \\
\text { leverer en sang så } \\
\text { banal at det grenser } \\
\text { til det pinlige: }\end{array}$ & $\begin{array}{l}\text { A synes det kommende } \\
\text { sitatet er pinlig banalt. } \\
\text { (Sim pga. kolonet). }\end{array}$ & $\begin{array}{l}\text { A er tvisynt og } \\
\text { ærlig. } \\
\text { A viser } \\
\text { kompetanse, } \\
\text { som tas for gitt } \\
\text { (evaluativ } \mathrm{SH} \text { ). }\end{array}$ & \\
\hline
\end{tabular}




\begin{tabular}{|l|l|l|l|}
\hline $\begin{array}{l}\text { 24) Vik ifra oss sorg } \\
\text { og død / vekk med } \\
\text { kaos, krig og nød / } \\
\text { gi oss blomster, ros } \\
\text { og frukt / ikkje } \\
\text { lidelser og tukt } \\
\text { («Dans på roser»). }\end{array}$ & $\begin{array}{l}\text { BE er banal og } \\
\text { pompøs. } \\
\text { A er real og } \\
\text { dyktig; han } \\
\text { belegger } \\
\text { påstandene } \\
\text { sine slik at } \\
\text { leserne kan } \\
\text { vurdere. }\end{array}$ & $\begin{array}{l}\text { Kan leseren stole på at } \\
\text { en anmelder som virker } \\
\text { forutinntatt, har valgt et } \\
\text { representativt sitat? }\end{array}$ \\
\hline $\begin{array}{l}\text { 25) Anmelderens } \\
\text { svar kan f.eks. være: } \\
\begin{array}{l}\text { Vik ifra oss, enkle } \\
\text { floskler / vekk med } \\
\text { nødrim og apostler. }\end{array}\end{array}$ & $\begin{array}{l}\text { BE er en dårlig poet. } \\
\text { A kan også rime og viser } \\
\text { suverenitet ved hjelp av } \\
\text { ironi. }\end{array}$ & $\begin{array}{l}\text { A har humor } \\
\text { og er lite } \\
\text { selvhøytidelig. }\end{array}$ & \\
\hline
\end{tabular}

Det kan virke som om Eidsvåg på plata viser til de hendelsene han forteller om i intervjuet. Men det virker ikke som om anmelderen er klar over denne forbindelsen. At det ikke blir påpekt, formidler inntrykket av anmeldelsen er skrevet på fritt og selvstendig grunnlag, uavhengig av intervjuet. Det kan bidra til å restituere Dagbladet-etosen som ble svekket i Eidsvåg-intervjuet.

Det er mye bygging av skribentens etos i anmeldelsen. Slik skiller teksten seg fra nyhetsartikkelen. Anmelderen bygger egen etos ved å vise (og vise til) egen kompetanse og ved å være morsom og lite selvhøytidelig. Men anmelderen svekker også egen etos gjennom tvetydigheter og språklige mangler.

Blant annet gjennom valg av språkhandling etablerer og understreker skribenten sin etos mer insisterende i anmeldelsen enn i intervjuet. Anmelderen må etablere sterk etos fordi han dømmer og konkluderer. I nyhetsjournalistikk er etos mer delt mellom kilde og skribent, men kildens etosetablering er sterkest markert.

\section{Lanseringsjournalistikk}

I en undersøkelse av norsk kulturjournalistikk fra 1964 til 2005 har Leif Ove Larsen en egen kategori for lanseringsintervju. Dette definerer han som «Intervju med aktør på kulturfeltet som skjer $i$ umiddelbar sammenheng med lansering av et kulturprodukt (bok, film, CD, utstilling, opptreden, konsert og lignende) på markedet» (Larsen 2008, s. 308). I Larsens undersøkelse utgjør lanseringsintervjuet $6 \%$ av kulturstoffet i 1964, $19 \%$ i 1984 og $28 \%$ i 2005.

Lanseringsintervjuet har hatt en kraftig vekst, men lanseringsjournalistikken har også blitt problematisert og kritisert. Cecilie Wright Lund har gjennom to utgivelser i 2000 og 2005 dokumentert og problematisert denne formen for journalistikk. På SKUP- konferansen i 2008 ble også lanseringsjournalistikken tatt opp som et eget emne. Også Dagbladets kulturredaktør mellom 2002 og 2009, Hege Duckert, sier de prøver å styre unna den rene lanseringsjournalistikken (Ny Tid 07.02.2004). 
Leif Ove Larsen skiller mellom forhåndsomtale (uten intervju), lanseringsintervju, nyhetsartikkel og reportasje. Grensene mellom nyhetsartikkel, reportasje og lanseringsintervju kan imidlertid være uklare. Eidsvåg-intervjuet vi har undersøkt, gir gjennom overskrift, bilde, bildetekst og ingress inntrykk av å være en nyhetsartikkel om noe annet enn Eidsvågs nye CD. Men teksten omtaler også Eidsvågs nye utgivelse, selv om denne omtalen kommer seint og utgjør en mindre del av artikkelen.

I en kommentar i Dagbladet i 2009 har Jo Nesbø en interessant definisjon av lanseringsjournalistikk:

'Lanseringsjournalistikk' er når mediene godtar premisset om at en forfatter, regissør, musiker, maler stiller opp til intervju i forbindelse med at de skal lansere noe, og derfor får lov til å si noe om det de skal selge. Mot at de sier noe annet også, noe som kan lage en overskrift, fange oppmerksomhet, noe som er person og ikke sak (Nesbø i Dagbladet 14.03.2009).

Nesbøs definisjon korresponderer godt med den symbiosen vi har avdekket $i$ vår analyse.

Lanseringsjournalistikk er uglesett i norske medier, men det forekommer ofte og mer eller mindre tildekket. Forfattere, musikere, skuespillere og regissører er gjester i talkshow eller dukker opp i avisintervjuer der de snakker om det de skal lansere - og om noe annet. For den som skal lansere et produkt, er det en gylden sjanse til å få oppmerksomhet. «[J]eg sier også ja til å sitte $i$ snakkesofaer i forbindelse med bokutgivelse selv om jeg vet at sytti prosent $a v$ samtalen vil handle om andre ting enn boka», skriver Jo Nesbø. For medieorganet er lanseringa en mulighet til å få en kjendis eller en kjent person i tale - gjerne om noe privat eller personlig. Noen ganger brukes lanseringsaspektet som en «aktualitetsknagg», andre ganger tildekkes det, slik at avisa, TV- eller radiokanalen i større grad beholder sin integritet. Sannsynligvis har kritikken mot lanseringsjournalistikken gjort at mediene har endret strategi.

Da Dagbladet intervjuet Eidsvåg i 2004, også den gangen i forbindelse med at han hadde gitt ut ny plate, var lanseringsaspektet langt mer synlig. Tittelen på saka var «Ble sint, og lagde ny plate», og ingressen «Dagbladet har møtt Bjørn Eidsvåg $i$ hytta hans på Geilo. Der skriver han sangene sine. Eidsvåg snakker om turnéliv, låtskriving og om hvor viktig det er å takle sin egen ensomhet» (Dagbladet 23.10.2004, s. 24). Plata ble anmeldt et annet sted i avisa.

I 2008 har Dagbladet endret strategi, muligens på grunn av presset mot lanseringsjournalistikken vi har omtalt over. I Eidsvåg-intervjuet vi har analysert, er i alle fall lanseringsaspektet tonet kraftig ned, og nye grep er tatt $\mathrm{i}$ bruk for å forklare at dette er en god sak verdt en dobbeltside. CD-utgivelsen nevnes nærmest i forbifarten.

Også da Eidsvåg ga ut plate i 2010, dekket Dagbladet utgivelsen som en nyhet om noe annet. I anledning CD-utgivelsen arrangerte nemlig Eidsvåg en «interaktiv pressekonferanse»; i stedet for å holde en normal pressekonferanse, skulle han arrangere pressekonferansen på Twitter. Settinga innebar at Eidsvåg fortløpende svarte på spørsmål han skulle få på Twitter. Dette gjorde han mens han satt på kafe, og mens Dagbladets journalist og fotograf fulgte ham. I tittelen løfter Dagbladet fram en av Eidsvågs kommentarer til et annet twitterutspill: «Hyller bildestuntet» (Dagbladet 21.9.2010, s. 40-41). Bildestuntet var NRK- 
journalist Helle Vaaglands twitterbilde av seg selv sparsomt påkledd, slik at en ikke helt perfekt kropp ble åpenbart - angivelig som en parodi på at kjendisene Demi Moore og Marianne Aulie kort før hadde publisert twitterbilder av seg selv med lett påkledning. Ved å hylle bildestuntet framstår Eidsvåg som fordomsfri, oppdatert og moderne. Om overskriften hadde fokusert på Eidsvågs plateutgivelse eller på at dette er en mediejippo (ordet jippo bruker Eidsvåg selv om arrangementet), ville Eidsvåg og Dagbladet framstått med en helt annen etos. Som i 2008 ledsages intervjuet i 2010 av en anmeldelse som en del av oppslaget.

\section{Pseudonyhet}

Lanseringsjournalistikken skaper en nyhet på bakgrunn av en pseudobegivenhet, som Allern inkluderer i det han kaller informasjonssubsidier (ferdiglagd materiale som journalisten får tilbud om å bruke) (1997, s. 249). Begrepet pseudobegivenhet sies å være brukt først i 1962 av Boorstin (1992). Pseudobegivenheter er, ifølge Sogn (2012):

i motsetning til hendelser som flyulykker eller naturkatastrofer, konstruerte nyheter. Dette innebærer at hendelsen ikke er spontan, men er planlagt, plantet eller satt i stand av noen. Videre karakteriseres pseudobegivenheter ved at de er satt i stand hovedsakelig, men ikke utelukkende, for å bli formidlet av mediene (s. 15).

Dette innebærer at når pseudobegivenheter skal presenteres som nyheter, bør de tilrettelegges slik at de samsvarer best mulig med etablerte nyhetskonvensjoner og nyhetskriterier.

Nyhetsartikler og nyhetsreportasjer er gjerne bygd opp slik at det viktigste presenteres først. Men i motsetning til i 2004 sender Dagbladet i 2008 uklare signaler om hvor viktig det er at Eidsvåg har gitt ut plate. Øverst i venstre hjørne i 2008 kan vi lese «Nytt Album» i hvit tekst på grønn bunn, nærmest som ei temaoverskrift. I teksten er derimot informasjonen om den nye plata plassert helt til slutt. Overskrifta forteller at Eidsvåg ble presset til å gi ut bok, stikktittelen forteller at Eidsvåg angrer, og ingressen forteller at boka har vært en belastning og gjentar at Eidsvåg angrer. Brødteksten begynner også med Eidsvågs anger. Som det står på sjette linje i brødteksten, så er det ett år siden biografien kom ut. Dette oppslaget kan altså ikke forsvares med at boka er ny. Teksten forteller også at Eidsvåg har hatt disse tankene om biografien en god stund: «han innrømmer at det har voert en vanskelig tid og en ubehagelig prosess». Selv om dette er gammelt nytt, făr det altså ei dobbeltside med forsidehenvisning.

Man snakker gjerne om journalistiske stoffkriteriene eller nyhetskriterier. I lærebøker i journalistikk listes det opp fire eller flere kjennetegn ved en god nyhet. I nyere norske lærebøker gjengis de gjerne som vesentlighet, aktualitet, sensasjon, identifikasjon og konflikt (Østlyngen og Øvrebø 1999). Kjendsli (2008) legger til eksklusivitet.

Til grunn for artikkelen «Presset til å gi ut boka om seg selv»kan det ligge et bredt spekter av nyhetskriterier. Det er sensasjonelt at en kjent mann angrer på at han bidro til sin egen selvbiografi. Vi kan identifisere oss med ham, han er en norsk familiemann som, ut over å være kjendis og artist, tilsynelatende lever et nokså vanlig liv. Intime detaljer fra ekteskapet og personlige tanker som anger gjør det også lettere å identifisere seg med kilden. Vi kjenner følelsesmessig nærhet. Dette understrekes gjennom at Eidsvåg omtales som «den populcere artisten». Konflikten formidles ikke eksplisitt før mot slutten av teksten, men er tydelig i tittel 
og ingress som en semantisk implikatur: Når Eidsvåg angrer på at han lot seg presse, innebærer dette at han er i konflikt med den som presset ham. At dette er ei eksklusiv sak, framgår av oppslagets omfang og av bilde, overskrift og uthevete sitater som forteller at Eidsvåg betror seg til Dagbladet. Aktualitetskriteriet er også med, men tones altså helt ned i artikkelen ved at det aktuelle stoffet kommer sist. Det grønne feltet med teksten «Nytt album» og anmeldelsen i spalten helt til høyre minner oss likevel om at Eidsvåg i disse dager er aktuell.

Det er for å skape en nyhet ut av en pseudobegivenhet at nyhetskriteriene brukes slik de gjør i lanseringsjournalistikk.

Sigurd Allern har pekt på at også økonomiske faktorer har en betydning for hva som blir en nyhet. Han supplerer derfor de tradisjonelle nyhetskriterier med det han kaller kommersielle nyhetskriterier. Allern skriver blant annet at «Jo større resurser i form av arbeidstid, personell og penger det koster å dekke en begivenhet, følge opp eller avsløre en sak, desto mindre sjanse er det for at det blir en nyhet», og «Jo dyktigere kilden, avsenderen, har tilrettelagt en sak journalistisk (kostnadene ved dette betales av kilden), desto større sjanse er det for at den blir prioritert som en nyhet» (Allern 2001, s. 66). Mens de tradisjonelle nyhetskriteriene er ment å forklare hva som er en god nyhet ut fra hensynet til leseren og hva hun vil interessere seg for, forklarer Allerns kommersielle nyhetskriterier hva som blir nyheter ut fra produksjonsmessige og økonomiske hensyn. En journalist kan si til sine lesere «les denne saken, den er aktuell og sensasjonell», men ikke «les denne saken, den var billig å produsere fordi jeg fikk alt i fanget». Det sier seg selv at hvis de kommersielle nyhetskriteriene har en betydning for at en nyhet blir en nyhet, så ønsker avisa å tone dem ned eller tildekke dem.

Dagbladet bruker nesten alle de tradisjonelle nyhetskriteriene for å overbevise leseren om at dette er en god nyhet. Lanseringsproblematikken og de kommersielle nyhetskriteriene tones naturlig nok ned. Aristoteles' beskrivelse av retorikk som «evnen til i enhver sak å se hvilke muligheter vi har til å overtale» samsvarer godt med Dagbladet anstrengelse for å presentere samarbeidet med Eidsvåg som god journalistikk: Alle muligheter er utnyttet (Aristoteles 2006, s. 27).

Nyheter forutsetter at kildens etos blir markert, fordi nyhetens sannhetsverdi avhenger av kildens etos. I en pseudonyhet som den analyserte er det kanskje særlig viktig, fordi den i stor grad handler om kildens karakter og person. Kildens etos er langt på vei nyhetens emne. Hvis nyheten f.eks. hadde vært at Eidsvåg var blitt slått ned på gata, hadde Eidsvågs etos spilt mindre rolle.

I Eidsvåg-intervjuet er mytene om kilden selve saka. Dermed er normkonteksten viktig. Fordi pseudonyheten i stor grad reproduserer gammelt nytt, blir mytene om kilden viktigere. Anmeldelsen derimot presenterer nytt innhold. Derfor spiller myter ei mindre rolle der, mens anmelderens kompetanse er viktigere. Anmelderen får etos først og fremst ved å vise seg som kompetent, og den kompetansen må vises faglig i anmeldelsen og ikke representeres ved mytiske forestillinger om anmelderen. 
I pseudonyheten er leseren trolig mindre opptatt av skribentens etos, fordi den ikke oppfattes som kritisk journalistikk. Leseren av anmeldelsen er ikke interessert i personen, men i produktet.

Begge tekster lanserer det samme produktet, men i intervjuet beskrives kilden. Derfor etableres kildeetos i stor grad gjennom semantiske implikaturer. Det skjer også i anmeldelsen, men siden anmelderen der ikke beskrives, men selv handler og er aktiv og tydelig - i større grad enn journalisten i pseudonyheten er - etableres anmelderens etos i stor grad gjennom språkhandlinger, som pragmatiske implikaturer. Vi har vist hvordan de to aktørene, Dagbladet og Bjørn Eidsvåg, ønsker å framstille Eidsvåg som ekte og autentisk. Hvis han ikke framstår som ekte, mister Eidsvåg etos, og samtidig vil Dagbladet miste ei sak. Dagbladet vil tone ned det iscenesatte for å skjule at de blir brukt, og for å skape et skinn av integritet og uavhengighet. Presseetisk er symbiosen og tildekkinga av den problematisk, men dette er også retorisk problematisk. For retorikken er også læra om hensiktsmessig kommunikasjon. Og Dagbladet spiller høyt. Den massive etosbygginga av Eidsvåg, samt tilsløringa av forholdet mellom avis og kilde kan true avisas etos. Avisa framstår som lite velvillig overfor sine lesere; den tildekker og er uærlig. Den framstår med en tvilsom moral og dermed med en svak karakter, og avisa kan virke både uforstandig og uklok. Samtlige av de tradisjonelle etosdimensjonene velvilje, karakterstyrke og klokskap, er truet.

\section{Litteratur}

Allern, S. (1997). Når kildene byr opp til dans. Pax, Oslo

Allern, S. (2001). Nyhetsverdier. Om markedsorientering og journalistikk i ti norske aviser. IJ-forlaget, Kristiansand

Aristoteles (2006). Retorikk. Vidarforlaget, Oslo

Boorstin, D. J. (1992). The Image: A Guide to Pseudo-events in America. Vintage Books

Dagbladet (23.10.2004) s. 24

Dagbladet (18.10.2008) s. 50-51

Dagbladet (21.9.2010) s. 40-41

Dahlén, P. (2008). Sport och medier. IJ-forlaget, Kristiansand

Entman, R. M. (1993). Framing: Toward Clarification of a Fractured Paradigm. I: Journal of Communication 43 (4)

Eriksson, O. (1999). «A generic communication model based on Habermas and Searle's versions of Speech act Theory» URL: http://mydocs.strands.de/mydocs/05663/05663.pdf [Lesedato: 2.4.2013]

Fairclough, N. (2008). Kritisk diskursanalyse. Hans Reitzels forlag, København Fairclough, N. (1992). Discourse and Social Change. Polity Press, Cambridge

Helland, K. (2003). Sport medier og journalistikk - med fotballandslaget til EM. Bergen. Fagbokforlaget.

Hellspong, L. (2000). «Berättelser i argumentation”, i Rhetorica scandinavica 16/2000

Hågvar, Y. B. (2007). A forstå avisa. Innføring i praktisk presseanalyse. Fagbokforlaget, Bergen

Johansen, A. (2002). Talerens troverdighet. Tekniske og kulturelle betingelser for politisk retorikk. Universitetsforlaget, Oslo

Kjeldsen, J. E. (2004). Retorikk $i$ vår tid. En innføring i moderne retorisk teori. Spartacus, Oslo

Kjeldsen, J. E. (2008). «Mediated publics and rhetorical fragmentation», i Carpentier, Nico et al. (eds.) Democracy, Journalism and Technology: New Developments in an enlargened Europe. Tartu University Press

Kjendsli, V. (2008). Rett på sak! Larebok I praktisk journalistikk. IJ-forlaget, Kristiansand

Kristensen, N. N. (2004). Journalister og kilder. Slinger $i$ valsen? À jour, Århus

Larsen, L. O. (2008). Forskyvninger. Kulturdekningen i norske dagsaviser $1964-2005$. I: K A Knapskog og L. O. Larsen (red.): Kulturjournalistikk. Pressen og den kulturelle offentligheten. 
Scandinavian Academic Press, Oslo

Ledin, P. (1997). «Med det nyttiga skola vi söka att förena det angenäma...». Text bild och språklig stil $i$ veckopressens föregångare. Svensk sakprosa, Lund

Levinson, S. C. (2000). Presumptive meanings. The MIT Press Cambridge Massachusetts

Lund, C. W. (2000). Kritikkens rom - rom for kritikk? Kulturstoffets rolle i dagspressen. Kunnskapsforlaget, Oslo

Lund, C. W. (2005). Kritikk og kommers. Kulturdekningen i skandinavisk dagspresse. Universitetsforlaget, Oslo

McCroskey, J. C. (2006). An Introduction to Rhetorical Communication. Pearson

Miller, C. (2001). «Genre som sosial handling» i Rhetorica Scandinavica 18/2001

Nesbø, J. (14.3.2009). «Oppmerksomhetsstrategier» I: Dagbladet

Ny Tid (7.2.2004). «Makten over omtalen» URL: http://www.nytid.no/arkiv/artikler/20040205/makten_over_omtalen/ Lesedato: 11.1.2012

Ricoeur, P. (1981). Hermeneutics and the human sciences. Cambridge University Press

Roksvold, T. (2005). Var avisspråket bedre før? Acta Humaniora nr. 224. Unipub, Oslo

Sigrell, A. (2001). Att övertyga mellan raderna. Rhetor

Sogn, C. G. (2012). Journalister og ideelle organisasjoner. En kvalitativ analyse av relasjonen mellom journalister og informasjonsmedarbeidere i ideelle organisasjoner. Masteroppgave i journalistikk, Institutt for medier og kommunikasjon, Universitetet i Oslo

Tekstreklameplakaten (2007). Norsk Presseforbund. URL: http://presse.no/Etiskregelverk/Tekstreklameplakaten. Lesedato: 13.12.2012

Togeby, O. (1977). Om Sprog. Reitzel. København

Tuchman, G. (1978). Making News. A Study in the Construction of Reality. Free Press, New York/London Var Varsom-plakaten (2008). Norsk Presseforbund. URL: http://presse.no/Etisk-regelverk/Vaer-VarsomPlakaten. Lesedato: 13.1.2012

Østlyngen, T. og Øvrebø T. (1999). Journalistikk. Metode og fag. Gyldendal, Oslo

Øyslebø, O. (1988). Ikkeverbal kommunikasjon. Universitetsforlaget, Oslo 
r---------

I Linn Vatne forelsket

seg og ofret barna

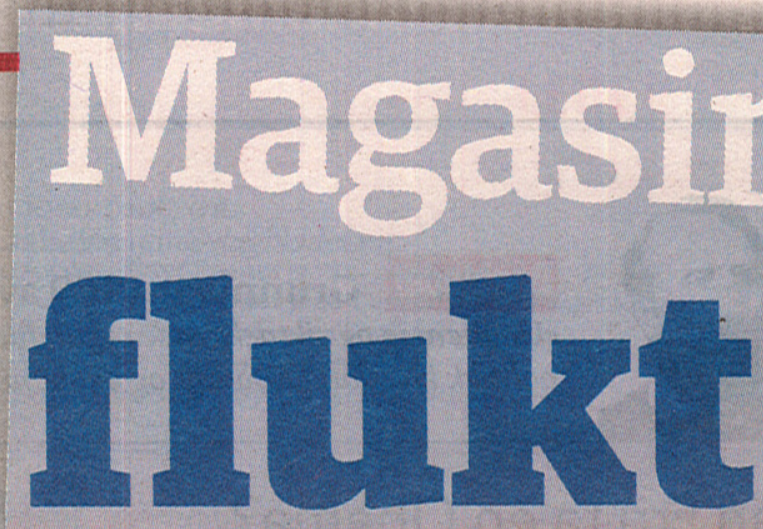

Min flukt

med Ole Christian Bach

MAGASINET, SIDE 20, 21, 22, 23, 24, 25, 26, 27, 28, 29, 30 OC 31

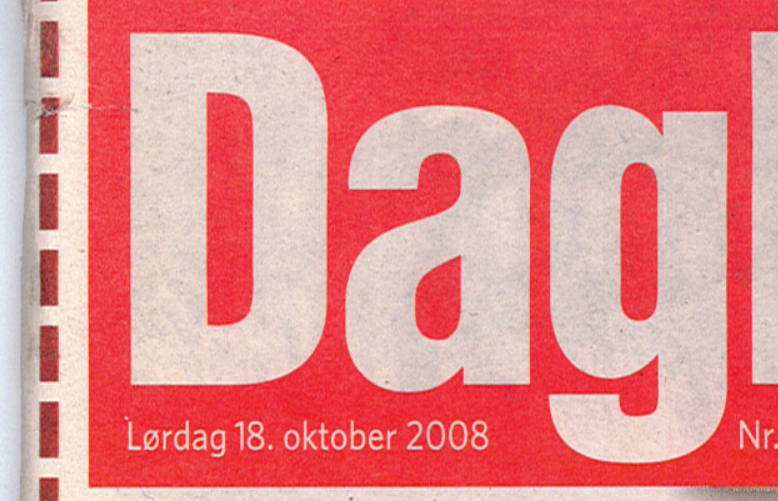

L-m-mon

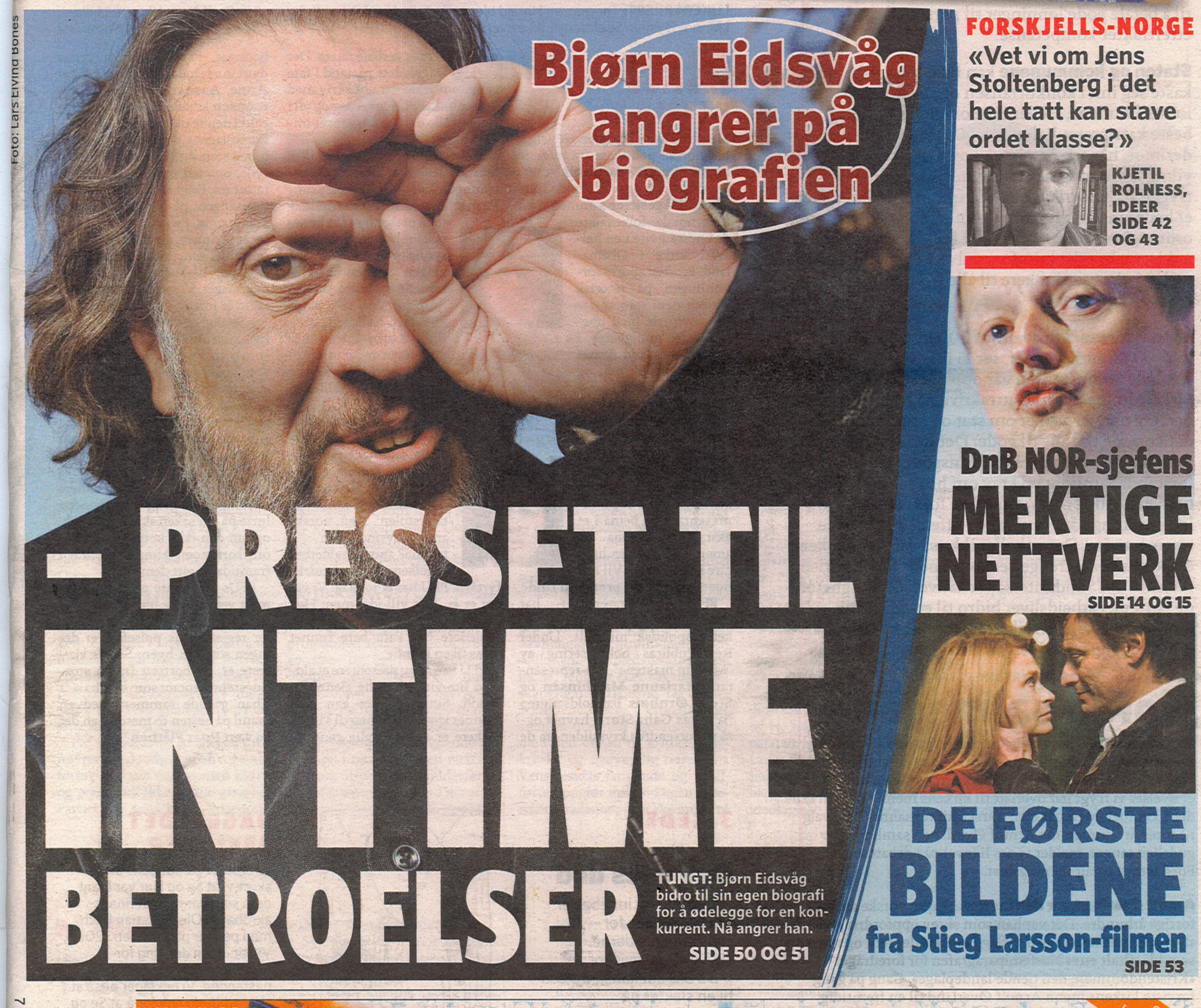

bildene

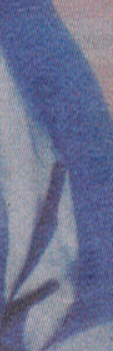




\section{NYTT ALВUИ}

O CV

\section{Bjørn Eidsvåg}

\section{- Født i Sauda i 1954.}

Gift med Ragnhild Idsøe siden 1974. Har barna Einar (30), Simen (26) og Lise (22).

- Har utgitt 21 album siden debuten «Inn for landing» $i$ 1976: «Bakerste benk». «Endelig voksen», «Live in Ny York»», «Passe gal»), «På leit», «Dansere i natten», «Vertigo», «Tatt av vinden», "Alt du vil ha», «Til alle tider», «Allemannsland», "Landet lenger bak», «Pa svai», «Tapt uskyld», «Hittil og littil», «Tålt»», «Skyfri himmel», «En vakker dag» himmel», «En vakke
«Nåde» og «Pust».

«Nåde» og «Pust». hederspris og har mottatt Spellemannprisen tre ganger. Har ti Spellemannnominasjoner. - En av Norges mestselgende artister. Samtlige gende artister. Samtlige utgivelser 000 eksemplasolgt i 100000 eksemplarer eller mer, med unntak av «Tapt uskyld» i 1999.

- «Tå|t»» solgte over 220000 eksemplarer. - Utdannet cand.theol. ved Menighetsfakultetet i Oslo 1980. Dette, i kombinasjon med musikkarriere, har gitt

ham tilnavnet rockepresten I fjor kom bok «Bjørn - en I fjor kom bok «Bjørn - en
biografi», skrevet av Randi biografi», skrevet
Berge Svendsen.

Berge Svendsen.
- Aktuell med «Pust», den siste i trilogien scm begynte med «Tålt» (2002) og «Nåde» (2006).

\section{Det var ut- leverende og ble en belast-} ning, ikke bare for meg, men for familien venner og kolleger.

Bjørn Eidsvåg

\section{Biografien om \\ Bjørn Eidsvåg har vært en stor be- \\ - lastning for ham \\ - og familien. Den populære artisten angrer på at han fortalte om sitt liv.}

\section{Tekst: Anders Gronneberg} agr@dagbladet.no

- Angrer, ja. Jeg bebreider ikke biograf Randi Berge Svendsen, hun gjorde en god jobb. Men jeg ville ikke tatt initiativ til bóka i

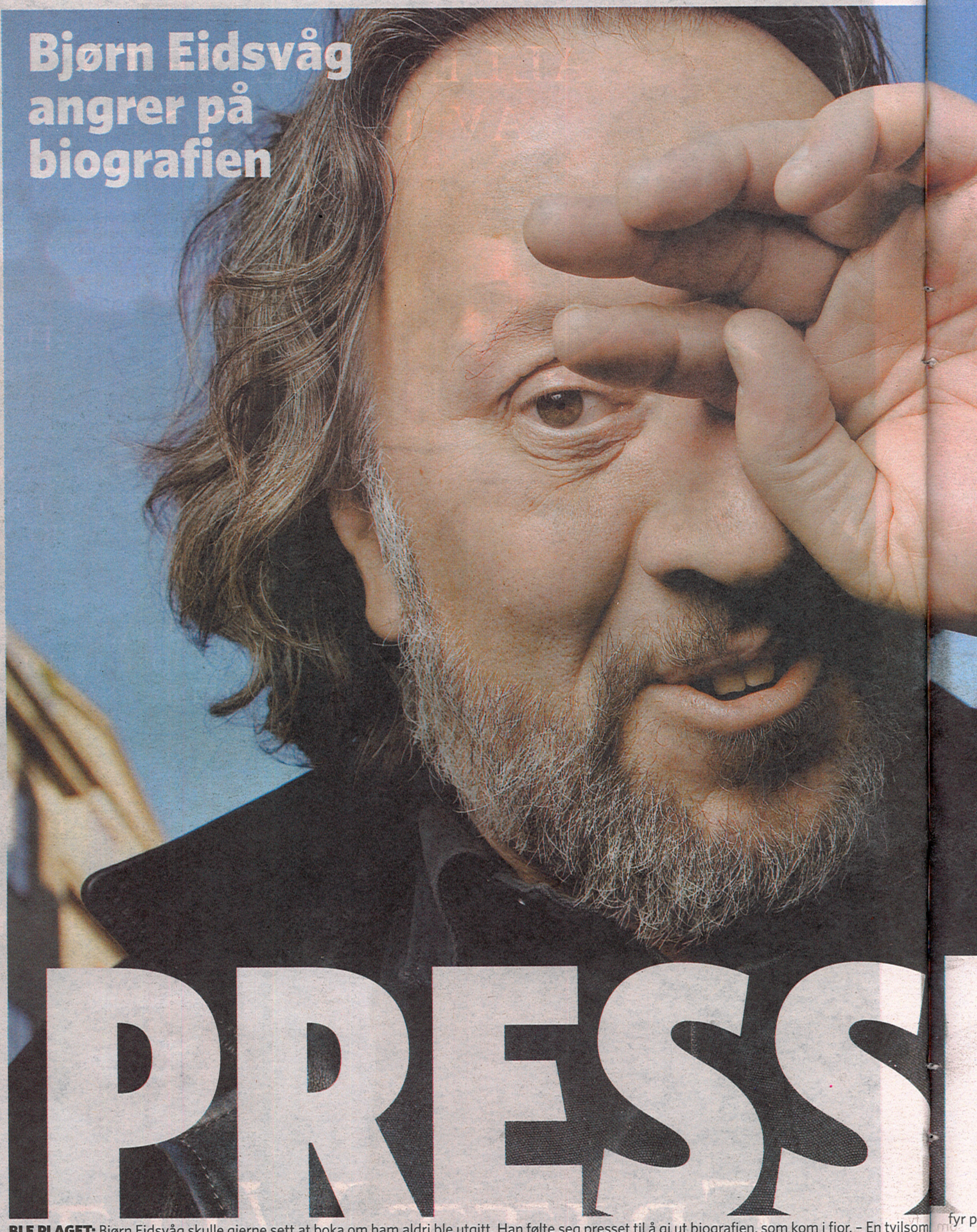

BLE PLAGET: Bjørn Eidsvåg

annen biograf, sier Eidsvåg.

dag, sier Bjørn Eidsvåg.

Det er et år siden boka «Bjørn - en biografi kom ut, og han innrømmer at det har vært en vanskelig tid og en ubehagelig prosess.

Belastning for kona

Bjørn Eidsvåg forteller videre at han ble forlegen og sjenert av mye av det som kom fram. Mediene og leserne grep boka med stort begix og kunne lese om blant annet da han midlertidig flyttet fra kona.

- Det var utleverende og ble en belastning, ikke bare for meg, men for familien, venner og kolleger.

- Spesielt kona følte belastningen stor, sier Bjørn Eidsvàg. - Jeg har alltid skjermet og vernet om familien. Kona syntes overhodet ikke noe om bokprosjektet. Det var mye der det ikke var hyggelig å bli minnet om, sier Bjørn Eidsvåg.

\section{Folte seg presset}

Det var Eidsvåg selv som tok initiativ til biografien. Det var ikke stort ego eller ønske om ei bok om seg selv som fikk ham til å ta kontakt med biograf Svendsen. Han følte seg presset til å giøre det.

- Det var noen tvilsomme folk som ønsket å lage en biograf om meg.

- Vedkommende plaget meg og mine nærmeste - ringte datteren min og andre rundt meg for å få ut opplysninger. Jeg var under press, leum og for å komme vedkommende i på 5, 8 millioner kroner. forkjøpet, tok jeg initiativ selv.
Eidsvåg har revurdert sitt syn på biografier:

- Jeg er ikke lenger sikker på at det er riktig at en biografi ska komme ut før en er død.

\section{Ga større selvinnsikt}

Men boka har ikke bare gjort livet en.

- Boka gjorde meg klokere, mindre høy på pæra og ga meg større selvinnsikt. Den giorde ogforholdet til kona sterkere.

Bjørn Eidsvåg er en pengemasin. Han sprøyter store penger inn i sitt selskap Quint, har full kont-Jeg ble slatt av Øystein Sun- de, men neste ar skal jeg ta ham, ler Eidsvàg før han tar en er alvorlig tone:

- leg er glad for å ha en så god $ø$ konomi. A tjene gode penger gjør meg ikke forlegen, og jeg håper det fortsetter. Det gir meg trygghet og mulighet til fortsatt å investere $i$ musikken og lage plater - de er ikke akkurat billige.

\section{Lar seg ikke mobbe}

Bjørn er involvert i et hytteprosjekt på Sørlandet sammen med (j) Nupen. I disse børskrakktider spørs det ikke om at dette kan bli et tapsprosjekt i stedet for en lur investering.

- Tanken har slått meg, sier Eidsvåg, som innrømmer at han er 


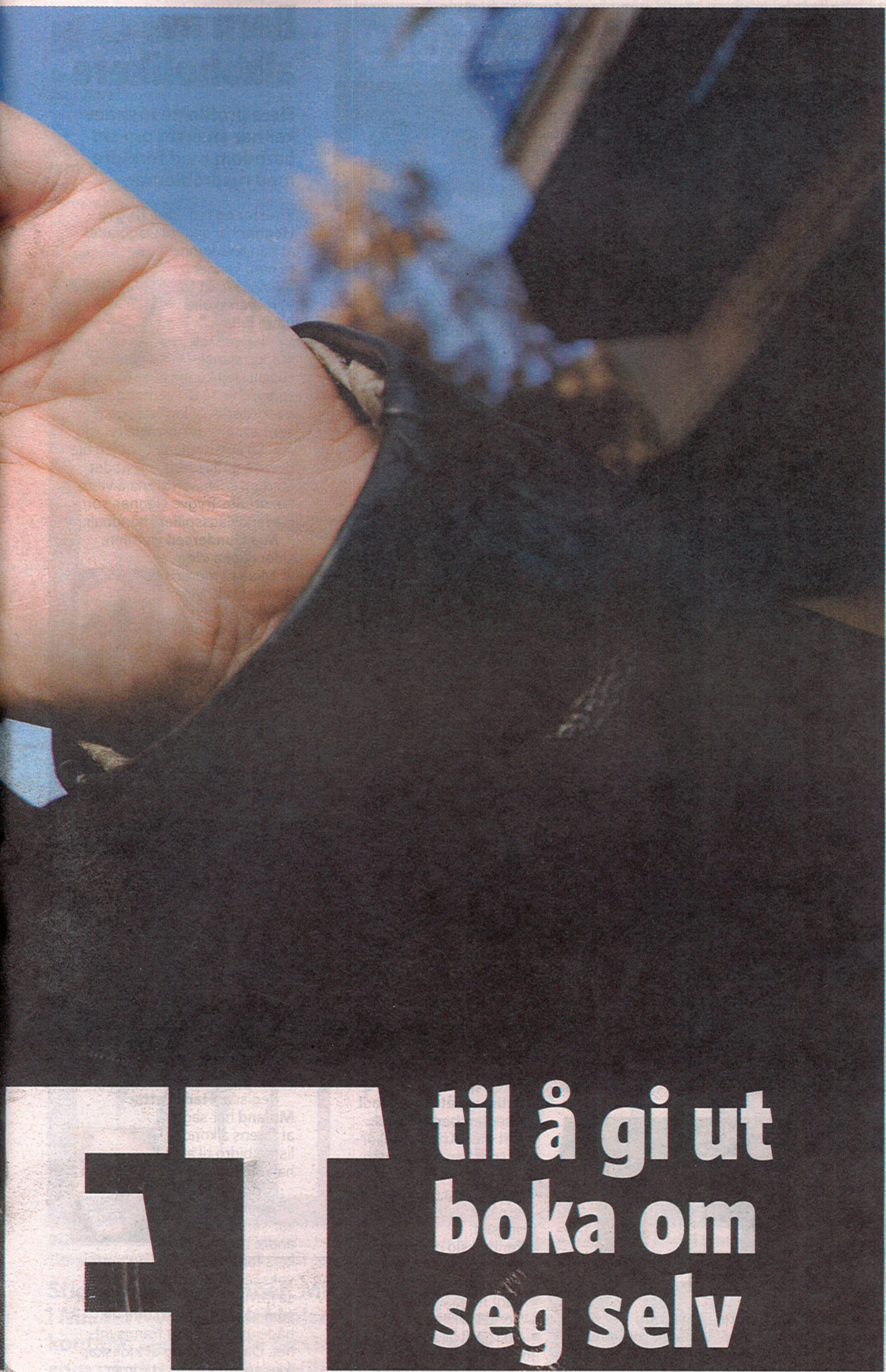

fyr plaget og presset meg om mine nærmeste for opplysninger. For å komme ham i forkjøpet, tok jeg selv kontakt med en

Foto: Lars Eivind Bones

glad i ting - alt fra sin lap top til hytta i Skurdalen.

Bjørn Eidsvåg er i dag ute med sitt 21. album - denne gangen uten duett med unge, vakre kvinner.

Men det er ikke fordi han føler seg mobbet av stempelet som gammel gris.

Jeg kommer nok til å gjøre det igjen. Jeg lar meg ikke skremme. Jeg blir forlegen i duettsituasjoner sammen med kvinner, sier Fidsvåg som forteller at det ser ertende dynamikk og en leken ertende dynamikk og en

\section{Livets gode krefter}

«Pust» er den siste plata $i$ en trilogi om livets store spørsmàl.
- "Tålt» omhandler mitt forhold til kjærligheten $i$ voksen alder. $P$ à den. På «P livets Albumet er spilt inn Sørlands-naust på et Ny-Hellesund, sammen med blant annet legenden Georg Riedel.

Det var magisk da han pakket t bassen. Riedel er mannen som lov Wreesvijk og spilte inn plater med Jan Johansson. Da han dro, sa han at dette var hans mest spektakulære innspilling. Han ville ikke engang ha betalt, sier Eidsvåg, som selvsagt sendte ham sin velfortjente hyre.

\section{- Presset ikke Eidsvåg}

Personen Bjørn Eidsvåg refererer til, tilbakeviser påstandene om at artisten ble presset. -

- Jeg hadde tre samtaler med Eidsvåg, og ikke pi noe tidspunkt resset jeg ham. Han var først ikke avvisende til en biografi, men siden opplyste han at det var noen andre som kom til å skrive ei bok, sier personen Eidsvåg refererer til.

Vedkommende nekter for å ha presset opplysninger ut av familien eller andre rundt Eidsvåg.

- En gang jeg ringte Eidsvåg var det sønnen som svarte, men da ba jeg kort og godt om å få snakke med Bjørn, sier personen som legger til at han liker svært dårlig at Eidsvåg framstiller detsom om vedkommende presset artisten tilå gi ut en annen biografi.
At Bjørn Eidsvåg selger mange plater er like sikkert som at han nekter å bryte med sin egen suksessformel. Det preger også «Pust».

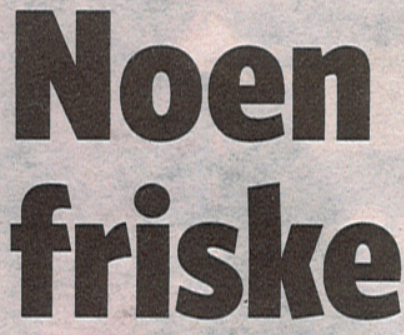

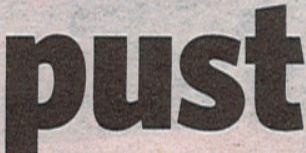

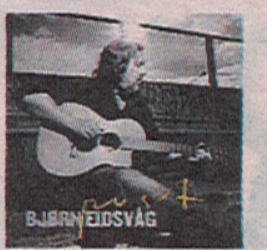

\section{Bjørn Eidsvåg}

"Pust»"

Sony $\mathrm{BMG}$

\section{Nesten irriterende på det jevne.}

Anmeldt av Øyvind Rønning oro@dagbladet.no

CDः Bjørn Eidsvåg har byttet ut deler av bandet og overlatt produksjonen til sin faste trommis Anders Engen (som har byttet ut seg sjøl med Madrugadas Erland Dahlen, og i stedet spiller perkusjon). Deter likevel ikke snakk om de store vvantesprangene, verken musikalsk eller tekstlig, når han nå avslutter trilogien som startet med "Tålt» og "Nåde».

\section{"Country-Bjorn»}

Med unntak av Geir Sundstøls gitarer, som med sin smakfulle pedal steel på fire spor introduserer herved "Country-Bjørn", og David Wallumrøds tangenter, ikke minst på «Blikket ditt» og "For seint», holder Eidsvåg seg i trygge, forutsigbare og godt kvalitetssikrede spor.

Det er ikke til å komme fra at han er blitt ganske flink til å gienta seg sjøl, og det er de nevnte herrer som skaper de små tilløp til magi som kan spores på plata. Det er gjort en del vellykte grep, men jeg tror Eidsvåg hadde tålt å bli strukket en god del lenger.

\section{Ingen duet}

I motsetning til de to forrige albumene i trilogien, har ikke dette en søt duett som kan virke som et lokomotiv for platesalget. Men han trenger det neppe. «E du den du e» er fengende nok, og det er lett å forstå at den er valgt som singel. Tittellåta og avsluttende «Sett at», platas beste spor kunne også gjort nytte som det. Det bærer bud om hva denne plata kunne blitt.

Med "Pust» uttaler Eidsvåg at han ønsker "å heie på livets gode kreftern, men så veldig gjennomført er det ikke. Her er mye kjærlighet og relasjoner mellom han og henne, men også store doser anger, moralsk forargelse, politisk og reliiøs indignasjon (uJerusalemu) 0 fra giøs indignasjon (uferusalem") og framfor al tungt opparbeidetlivserfaring. "Svart mane» er en besk virkelighetsbeskrivelse signert Svovelpredikant-Eidsvåg: Lucifer sko me aldri ha kysst/ men me gjor det, og det med grådig lyst (...) Me forgifta brystet som amma oss / og hadd ikkje vett te å skamma oss / me henga oss te det som bryte ner / nå e apokalypsen her.

\section{Banalt}

i møter en oppriktig og sårbar Eidsvåg, men også Pludre-Eidsvåg. Han er en solid ordsnekker men ikke mer enn at han leverer en sang så banal at det grenser til det pinlige: Vik ifra oss sorg og død/vekk med kaos, krig og nød/gi oss blomster ros og frukt / ikkje lidelser og tukt («Dans på roser»).

Anmelderens svar kan f.eks, være: Vik ifra oss, enkle floskler / vekk med nødrim og apostler. 